\title{
One-Pot Synthesis of Fluorescent 2,5-Dihydro-1,2,3-triazine Derivatives from a Cascade Rearrangement Sequence in the Reactions of 1,2,3-Triazolium-1-aminide 1,3-Dipoles with Propiolate Esters
}

\author{
Richard N. Butler, ${ }^{*}{ }^{\dagger}$ Aoife M. Fahy,$^{\dagger}$ Anthony Fox, ${ }^{\dagger}$ John C. Stephens, ${ }^{\dagger}$ P. McArdle $^{\dagger}$ \\ D. Cunningham, ${ }^{\dagger}$ and A. Ryder ${ }^{\dagger, \neq}$ \\ Chemistry Department and National Centre for Biomedical Engineering Science, National University of \\ Ireland, Galway, Ireland \\ r.debuitleir@nuigalway.ie
}

Received April 10, 2006

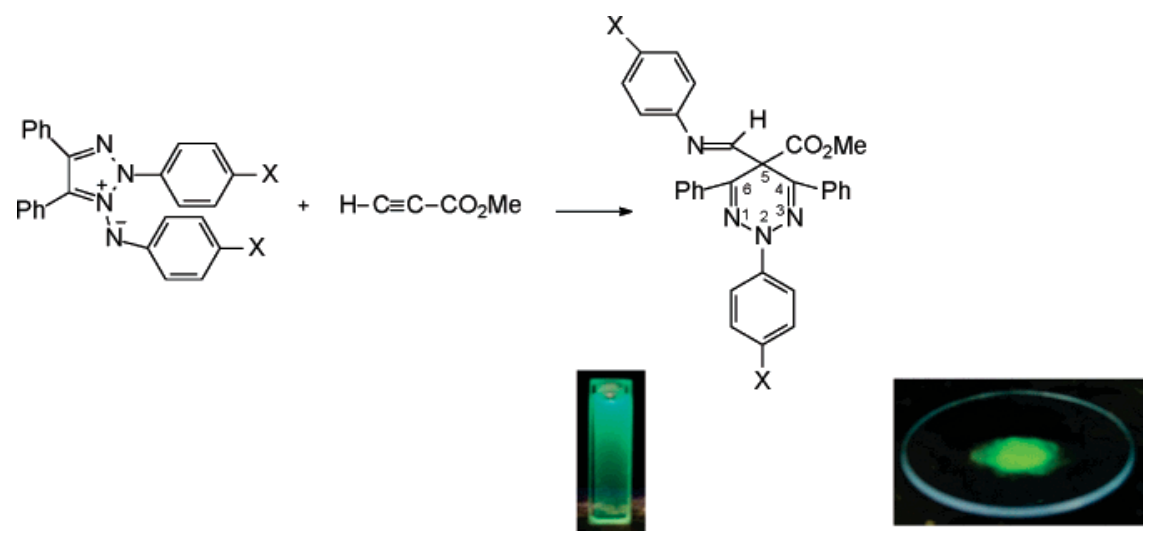

The reactions of 1,2,3-triazolium-1-aminides 1 (readily available from benzil bishydrazones) with propiolate esters leads to fluorescent 2,5-dihydro-1,2,3-triazine derivatives $\mathbf{2}, \mathbf{3}$ in one pot. These synthetic reactions can be carried out in acetone, in water, or under solvent-free conditions. The reactions involve a Huisgen cycloaddition followed by a sequence of rearrangements. The final ring-expansion step was blocked by linking a six-methylene hydrocarbon chain between the prospective 1,2,3-triazine C-4 and C-6 atoms, using substrate $\mathbf{8}$ which gave the fused tricyclic azapropellane product $\mathbf{9}$ exclusively. X-ray crystal structures were determined for two 2,5-dihydro-1,2,3-triazine derivatives and for compound $\mathbf{9}$. The UV absorption of the 1,2,3-triazine derivatives showed a dual absorption at ca. 310 and ca. $390 \mathrm{~nm}$ with fluorescent emission at ca. 480 and $528 \mathrm{~nm}$ (for excitation at $317 \mathrm{~nm}$ ). The significant Stokes shift of ca. $200 \mathrm{~nm}$ shows the potential for biological fluorescent labeling experiments.

\section{Introduction}

Fluorescent molecules with reactive functional groups have received considerable recent interest because of their potential for incorporation as real-time sensors in biomolecular systems. ${ }^{1-8}$

\footnotetext{
${ }^{\dagger}$ Chemistry Department.

‡ National Centre for Biomedical Engineering Science.

(1) Wiskur, S. L.; Ait-Haddou, H.; Anslyn, E. V.; Lavigne J. J. Acc. Chem. Res. 2001, 34, 963-972.

(2) Han, M. S.; Kim, D. H. Angew. Chem., Int. Ed. 2002, 41, 3809-

(3) Li-Li, Z.; Hao, S.; Hua-Ping, L.; Hui, W.; Xiao-Hong, Z.; Shi-Kang, W.; Shuit-Tong, L. Org. Lett. 2004, 6, 1071-1074.
} 3811.
Among the triazine series, the 1,2,3-triazine system is the least studied by comparison with 1,2,4- and 1,3,5- triazine structures because the ring system is the least stable of the three and synthetic routes are limited. ${ }^{9}$ Herein we describe ${ }^{10}$ an experi-

(4) Krishnamoorthy, S.; Fang, X.; Brandon, M. C.; Su, L.; Hannah, N. B.; Qian, W. Org. Lett. 2004, 6, 4603-4606.

(5) Moerner, W. E.; Orrit, M. Science 1999, 283, 1670-1676.

(6) Willets, K. A.; Ostroverkhova, O.; He, M.; Twieg, R. J.; Moerner, W. E. J. Am. Chem. Soc. 2003, 125, 1174-1175.

(7) Rigler, R., Orrit, M., Basche, T., Eds.; Single Molecule Spectroscopy; Nobel Conference Lectures; Springer-Verlag: Berlin, Germany, 2001; Vol. 67.

(8) Weiss, S. Science 1999, 283, 1676-1683. 
SCHEME 1. Some Key ${ }^{1} \mathrm{H}$ and ${ }^{13} \mathrm{C}$ NMR Shifts in $\mathrm{CDCl}_{3}$ for 2a and 4a

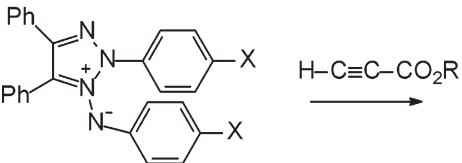

1 a $X=H$

$\mathrm{b} X=\mathrm{OMe}$

$\mathrm{c} X=\mathrm{Br}$

$\mathrm{dX}=\mathrm{Cl}$

$\mathrm{e} X=\mathrm{NO}_{2}$

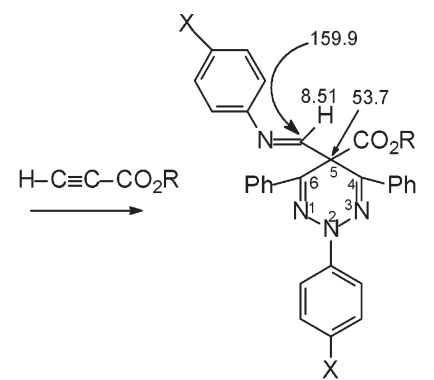

$2 \mathrm{R}=\mathrm{Et}$

$3 \mathrm{R}=\mathrm{Me}$

$$
\downarrow \text { aq. EtOH }
$$<smiles></smiles>

$6 \mathrm{R}=\mathrm{Et}$

$7 \mathrm{R}=\mathrm{Me}$

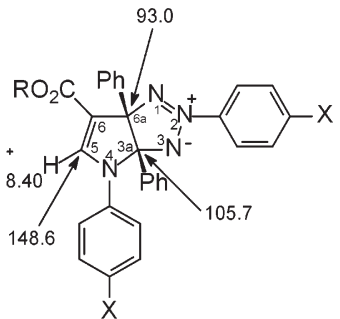

$4 \mathrm{R}=\mathrm{Et}$

$5 \mathrm{R}=\mathrm{Me}$ mentally simple one-pot reaction which produces new fluorophore derivatives of the 2,5-dihydro-1,2,3-triazine structure containing reactive functional groups of an ester and an imine suitable for bonding. We explore the multistep synthetic pathway which produces these products. This work has developed from our studies ${ }^{11}$ of azolium ylide systems where two of the four $\pi$ electrons of a potential 1,3-dipole ${ }^{12}$ are embedded in an azole ring.

\section{Results and Discussion}

1. Synthesis and Mechanism. When solutions of the 1,2,3triazolium-1-aminide 1,3-dipoles 1 were treated with unsymmetrical alkyl propiolates in dry acetone and heated for $24 \mathrm{~h}$ under reflux, the substituted 1,2,3-triazine derivatives $\mathbf{2}$ and $\mathbf{3}$ were obtained in reasonable yields along with lesser yields of the fused pyrrolo[2,3- $d$ ]-triazoline derivatives $\mathbf{4}$ and $\mathbf{5}$ (Scheme 1 , Table 1). When the reaction was carried out in undried acetone quantities of a third product, 6 and 7 were also encountered from hydrolytic degradation of 2 and 3 . This degradation could also be carried out in high yield by separately heating solutions of 2 and 3 in 1:1 (v/v) aqueous ethanol. The

(9) For a review see the following: Ahsawa, A.; Itoh, T. 1,2,3-Triazines and their Benzo Derivatives. In Comprehensive Heterocyclic Chemistry II; Katritzky, A. R., Rees, C. W., Scriven, E. F., Eds.; Elsevier Science: New York, 1996; Vol. 6, pp 483-505.

(10) Part of this work has been published in preliminary communication form: Butler, R. N.; Fahy, A. M.; Fox, A.; Stephens, J. C.; McArdle, P.; Cunningham, D.; Ryder, A. G. Tetrahedron Lett. 2006, 47, 1721-1724.

(11) Butler, R. N.; Cloonan, O. M.; McArdle, P.; Cunningham, D. J. Chem. Soc., Perkin Trans. 1 1998, 1295-1297. Butler, R. N.; Wallace, L. M. J. Chem. Soc., Perkin Trans. 1 2000, 4335-4338.

(12) A survey of 1,3-dipolar cycloadditions can be found in the following: Huisgen, R. In 1,3-Dipolar Cycloaddition Chemistry; Padwa, A., Ed.; John Wiley \& Sons : New York, 1984; vVol. 1, pp 1-176.
TABLE 1. 2,5-Dihydro-1,2,3-triazines and Pyrrolo Triazoline Products

\begin{tabular}{ccccccc}
\hline & & yield & & & yield \\
entry & product & $\begin{array}{c}\text { (\%) } \\
(\%)^{a}\end{array}$ & $\mathrm{mp}^{\circ} \mathrm{C}$ & product $^{\circ} \mathrm{C}$ \\
\hline 1 & $\mathbf{2 a}$ & 52 & $122-123$ & $\mathbf{4 a}$ & 8 & $186-187$ \\
2 & $\mathbf{2 b}$ & 52 & $140-141$ & $\mathbf{4 b}$ & 0 & \\
3 & $\mathbf{2 c}$ & 35 & $193-194$ & $\mathbf{4 c}$ & 23 & $157-158$ \\
4 & $\mathbf{2 d}$ & 45 & $179-180$ & $\mathbf{4 d}$ & 27 & $174-175$ \\
5 & $\mathbf{2 e}$ & 38 & $165-167$ & $\mathbf{4 e}$ & 33 & $172-174$ \\
6 & $\mathbf{3 a}$ & 38 & $146-147$ & $\mathbf{5 a}$ & 13 & $164-166$ \\
7 & $\mathbf{3 b}$ & 33 & $144-145$ & $\mathbf{5 b}$ & 8 & $145-146$ \\
8 & $\mathbf{3 c}$ & 26 & $163-164$ & $\mathbf{5 c}$ & 35 & $169-170$ \\
9 & $\mathbf{3 d}$ & 33 & $158-159$ & $\mathbf{5 d}$ & 25 & $163-164$ \\
10 & $\mathbf{3 e}$ & 29 & $213-214$ & $\mathbf{5 e}$ & 25 & $143-144$ \\
11 & $\mathbf{6}$ & 72 & $142-143$ & & & \\
12 & $\mathbf{7}$ & 92 & $193-194$ & & & \\
13 & $\mathbf{8}$ & 46 & $173-174$ & & & \\
14 & $\mathbf{9}$ & 85 & $159-161$ & & &
\end{tabular}

${ }^{a}$ Yield of isolated product after recrystallization.

degradation occurred either under nitrogen or in air and produced formanilide and aniline along with triazines 6 and 7 .

It probably involved acid catalyzed addition of water to the imine and competitive fragmentation as shown in Scheme 2 giving formanilide (path $\mathrm{A}$ ) as well as a formyl group at the triazine C-5 (path B). Both formanilide and aniline were isolated as products from the degradation. In path $\mathrm{B}$, air oxidation of the formyl group and ready decarboxylation gives the $5-\mathrm{H}$ triazine 6. These reactions are probably driven by the special leaving-group ability of the extensively delocalized anion of 2,4,6-triaryl-5-alkoxycarbonyl-2-5-dihydro-1,2,3-triazines 6 and 7. These compounds exhibit proton deuterium exchange at C-5 when dissolved in ROD solvents containing alkoxide base but not in the absence of the base. When the degradation was carried out in a 1:1 (v/v) EtOD- $\mathrm{D}_{2} \mathrm{O}$ mixture, compound 7, deuterated 
SCHEME 2. Tr-H Is Compound 6 or 7

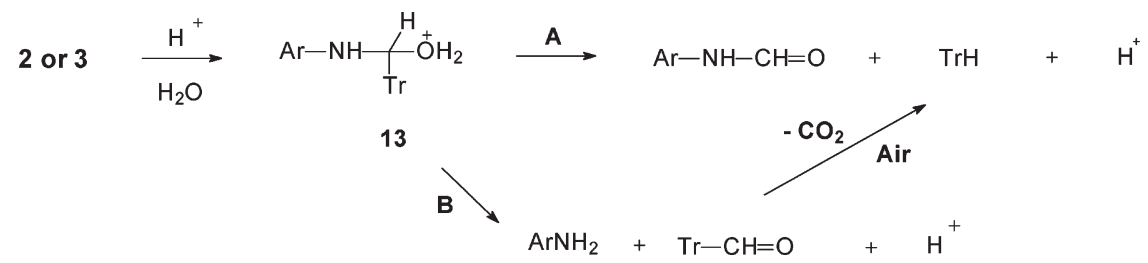

TABLE 2. Fluorescent Properties, Absorption, and Emission of the Series 3 and Compound 7

\begin{tabular}{ccccccc}
\hline & $\begin{array}{c}\lambda_{\text {abs } \max ^{a}} \\
\text { band 1 } \\
(\mathrm{nm})\end{array}$ & $\begin{array}{c}\epsilon_{\mathrm{abs}} \max \\
\text { band 1 } \\
\left(\mathrm{M}^{-1} \mathrm{~cm}^{-1}\right)\end{array}$ & $\begin{array}{c}\lambda_{\text {abs } \max ^{a}} \\
\text { band 2 } \\
(\mathrm{nm})\end{array}$ & $\begin{array}{c}\text { area ratio }^{b} \\
(\mathrm{est})\end{array}$ & $\begin{array}{c}\lambda_{\mathrm{em}} \max ^{c} \\
\text { band 1 } \\
(\mathrm{nm})\end{array}$ & $\begin{array}{c}\lambda_{\text {em }} \max ^{c} \\
\text { band 2 } \\
(\mathrm{nm})\end{array}$ \\
\hline 3a & 307 & 19914 & 392 & 1.5 & 483.6 & 528.7 \\
3b & 307 & 18213 & 391 & 2.0 & 483.7 & 528.2 \\
3c & 310 & 25971 & 391 & 3.1 & 482.6 & 528.1 \\
3d & 309 & 26540 & 391 & 1.7 & 482.8 & 528.1 \\
3e & 378 & 30548 & & & 499 & \\
7 & 322 & 19192 & 377 & 1.1 (est) & 478.9 & 516.7
\end{tabular}

${ }^{a}$ Steady-state excitation data recorded with the irradiation set at 470 $\mathrm{nm}$ and at a concentration of $10^{-6} \mathrm{M}$ in $\mathrm{MeOH} .{ }^{b}$ Estimated approximate area ratios band 1/band 2 from best fit Gaussian functions at the offset baseline. ${ }^{c}$ Steady-state emission data recorded with $317 \mathrm{~nm}$ excitation at a concentration of $10^{-6} \mathrm{M}$ in $\mathrm{MeOH}$.

at C-5, was obtained thereby confirming the presence of the carbanion in the reaction.

The compounds $\mathbf{2}$ and $\mathbf{3}$ displayed a green fluorescence (Table 2) which was a property of the dihydrotriazine unit. This fluorescence was retained in compounds $\mathbf{6}$ and 7. The pyrrolo[2,3-d]-1,2,3-triazoline products $\mathbf{4}$ and $\mathbf{5}$ were precursors to the 2,5-dihydro-1,2,3-triazine products 2 and $\mathbf{3}$. When compounds $\mathbf{5 a}$ and $\mathbf{5 d}$ were separately heated under reflux in acetone for $24 \mathrm{~h}$, the triazines 3a and 3d were obtained in 24 and 20\% yields, respectively. In the overall reaction from substrates $\mathbf{1}$, the yields of the fluorescent triazines were increased and reduced by the presence of electron donating and electron withdrawing $\mathrm{X}$-substituents, respectively, for standard synthetic conditions (Scheme 1, Table 1) (suggesting that stabilization of the triazolium terminus of the intermediate $\mathbf{1 2}$, Scheme 3 , facilitates the ring expansion). For the reaction of the parent substrate 1a with methyl propiolate, it was found that with water as the medium, where both reactants are insoluble, a reaction at 90 ${ }^{\circ} \mathrm{C}$ for 24 h gave the product 3a in $79-81 \%$ yield along with only $6-7 \%$ of $7 \mathbf{a}$. Interestingly, water enhanced the in situ conversion of the pyrrolo[2,3-d]-1,2,3-triazoline 5a to the triazine 3a but without an organic cosolvent did not significantly hydrolyze the imine group in the latter. Breslow ${ }^{13}$ first established the beneficial effects of water as a solvent for organic synthetic reactions where the hydrophobic effect ${ }^{13}$ plays a key role.

We have also recently observed ${ }^{14}$ successful cycloadditon reactions in water with insoluble phthalazinium dicyanomethanide 1,3-dipoles and liquid dipolarophiles. Under solvent-free conditions when the solid 1,3-dipole 1a was mixed with an equimolar quantity of liquid methyl propiolate (neither in excess as potential solvent) in a glass tube and heated at $60{ }^{\circ} \mathrm{C}$ for $1 \mathrm{~h}$, the fluorescent product 3a was obtained in $71 \%$ yield. Hence,

(13) Breslow, R.; Rideout, D. J. Am. Chem. Soc. 1980, 102, 7816-7817. Biscoe, M. R.; Breslow, R. J. Am. Chem. Soc. 2002, 125, 12718-12719. Breslow, R. Acc. Chem. Res. 2004, 37, 471-478.

(14) Butler, R. N.; Coyne, A. G.; Cunningham, W. J.; Burke, L. A. J. Chem. Soc., Perkin Trans. 2 2002, 1807-1815. the experimental requirements for these one-pot multistep synthetic reactions are particularly beneficial as to both laboratory and environmental considerations.

The formation of the products $\mathbf{2}$ and $\mathbf{3}$ involves a cascadetype sequence of rearrangements from the initial cycloadduct $\mathbf{1 1}$ (Scheme 3). We have established ${ }^{15}$ that the 1,2,3-triazolium1-aminide 1,3-dipole 1 undergoes $\mathrm{HOMO}_{\text {dipole }}$ controlled Huisgen cycloaddition ${ }^{12}$ reactions. The exclusive regiochemistry in the products $\mathbf{2}-\mathbf{5}$, observed herein for the first time, where the $\mathrm{N}^{-}$terminus has bonded to the unsubstituted carbon of the alkyne, is in agreement with this. The initial cycloadduct $\mathbf{1 1}$ undergoes a symmetry-allowed suprafacial 1,4-sigmatropic rearrangement to give the products $\mathbf{4}$ and $\mathbf{5}$. We have characterized $^{12,15}$ more stable examples of these types of products from both alkene and general $\mathrm{X}=\mathrm{Y}$ dipolarophiles (where there is now no $\mathrm{C}=\mathrm{C}$ in the analogous species $\mathbf{1 1}$ ). We have recently commented ${ }^{16}$ on the significance of this rearrangement which is a nitrogen analogue of the ubiquitous 1,5-rearrangements of 1,3-diene systems allowed by Woodward-Hofmann HOMO symmetry. In the present reactions the products $\mathbf{4}$ and $\mathbf{5}$ are the first cases with both an $\mathrm{H}$ atom at C-5 (Scheme 1) and a double bond at C-5 and C-6 and they are highly labile, rearranging in situ with ring expansion. We envisage that this ring expansion occurs through the dipolar intermediate 12 (Scheme 3) which arises from heterolytic cleavage of the $\mathrm{C}(3 \mathrm{a})-\mathrm{N}(4)$ bond in the products 4 and 5 (Scheme 3).

It was of interest to explore whether the ring expansion to the 1,2,3-triazine derivative would still occur if the C-3a and C-6a bridgeheads of compounds 5 were linked with a sufficiently long chain, for example, six methylene groups (indicated by Dreiding models). This would give the product $\mathbf{1 0}$ (Scheme 4). The 1,3-dipole 8 was synthesized from DL trans1,2-cyclooctanediol by oxidation followed by bisarylhydrazone formation and subsequent oxidation of the bisarylhydrazone to the 1,3-dipole $\mathbf{8}$. The sole product from the reaction of $\mathbf{8}$ with methyl propiolate was the tricyclic compound 9 (85\%), formed from the cycloaddition and 1,4-rearrangement steps. This product could not be induced to rearrange to the structure $\mathbf{1 0}$. A referee has pointed out that this result is not surprising since the structure may force the dihydrotriazine ring toward planarity thereby becoming approximately isosteric with the strained [4] meta cyclophane. ${ }^{17}$ However since there are six methylene groups linking the triazine $\mathrm{C}-3$ to $\mathrm{C}-5$ in structure $\mathbf{1 0}$, the strain should be lessened as inferred by the Dreiding models, but it still could be significant. Another effect of the six methylene chain may be to destabilize the intermediate $\mathbf{1 2}$ both sterically and by loss of phenyl stabilization of the cationic terminus of the ylide thereby preventing the ring expansion.

(15) Butler, R. N.; Lysaght, F. A.; Burke, L. A. J. Chem. Soc., Perkin Trans. 2 1992, 1103-1106.

(16) Butler, R. N.; Coyne, A. G.; Cunningham, W. J.; Moloney, E. M.; Burke, L. A. Helv. Chim. Acta 2005, 88, 1626-1628.

(17) Tsuji, T. In Modern Cyclophane Chemistry; Gleiter, R., Hopf, H., Eds.; Wiley: New York, 2004; pp 81-104. 
SCHEME 3

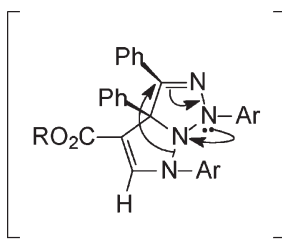

11

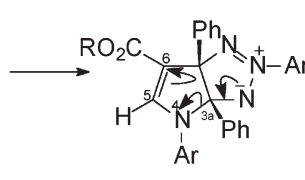

4,5

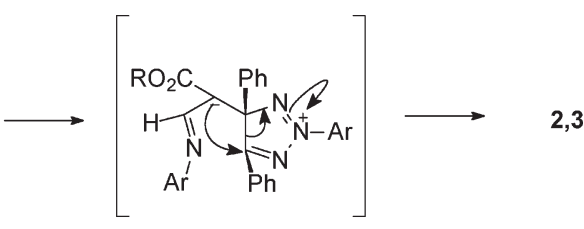

12

SCHEME 4. Ar, $p-\mathrm{NO}_{2}-\mathrm{C}_{6} \mathrm{H}_{4} \cdot{ }^{1} \mathrm{H}$ and ${ }^{13} \mathrm{C}$ NMR Shifts in $\mathrm{CDCl}_{3}$<smiles>CC#CC#CC(C)=O</smiles>

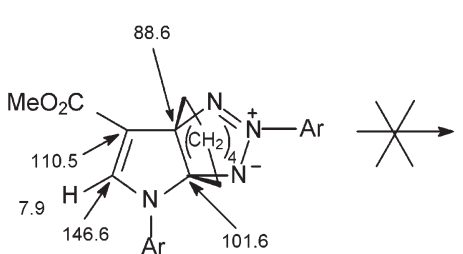

9
2. Product Structures. The structures of the products $\mathbf{2}-\mathbf{7}$ and 9 were established from microanalyses, IR, and proton and carbon-13 NMR spectra which showed all of the expected signals and multiplicities. Representative examples of some key chemical shifts are shown in Schemes 1 and 4. The carbon-13 NMR assignments were supported by DEPT spectra. The structures $\mathbf{4}, \mathbf{5}$, and 9 contain an embedded enamine moiety at $\mathrm{N}-4, \mathrm{C}-5$, and C-6 within the dihydropyrrole ring. The $\alpha$ - and $\beta$ - enamine sites (C-5 and C-6, respectively) showed the expected deshielding and shielding associated with the enamine resonance,

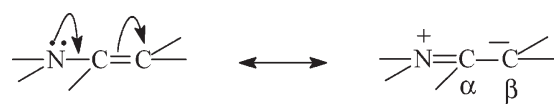

The regiochemistry of the cycloaddition in the structures $\mathbf{4}$ and 5 was established by locating the original alkyne proton at C-5 through carbon-13 distortionless enhancement by polarization transfer (DEPT) spectra and by proton nuclear Overhauser effect (NOE) difference spectra which showed strong enhancements (11-13\%) between $\mathrm{H}-5$ and the 4-N-phenyl $\mathrm{H}_{\text {ortho }}$ signals. The product structures were further supported with X-ray crystal structure determinations on compounds $\mathbf{3 a}, \mathbf{7 a}$, and $\mathbf{9}$ (Figures $1-3$, respectively, in Supporting Information). The X-ray structures of compounds $3 \mathbf{a}$ and $7 \mathbf{a}$ show some crowding and twisting of the substituents on the C-4, C-5, and C-6 carbons of the dihydro-1,2,3-triazine ring so that there is no plane of symmetry through the N-2, C-5 axis, and the carbons at C-4 and C-6 show slightly different carbon-13 NMR signals.

3. Fluorescent Properties. Compounds $\mathbf{3 a}-\mathbf{d}$ display two strong absorption bands below ca. $400 \mathrm{~nm}$, the first at ca. 300 $\mathrm{nm}$ and the second at ca. $400 \mathrm{~nm}$ (Table 2). Excitation of compounds $\mathbf{3 a}-\mathbf{d}$ and 7 at ca. $300 \mathrm{~nm}$ (Figure 1) or ca. 400 $\mathrm{nm}$ results in a dual band (480 and $530 \mathrm{~nm}$ bands) emission centered at ca. $520 \mathrm{~nm}$, which is sensitive to the excitation wavelength used (Figure 2A). The nitro substituted compound 3e has only a single very weak emission band. Excitation at ca. $320 \mathrm{~nm}$ leads to more intense emission than $400 \mathrm{~nm}$ excitation (about 2.5 times), and the ratio is approximately equal to the intensity ratio of the absorption bands. The wavelength of excitation also influences the ratio of the two emission bands (Figure 2A). In the case of 3a the ratio between band 1 (480 $\mathrm{nm})$ and band $2(530 \mathrm{~nm})$ increases from 0.6 to 1.2 on going from 317 to $400 \mathrm{~nm}$ excitation (Table 3, column 7 and 8).

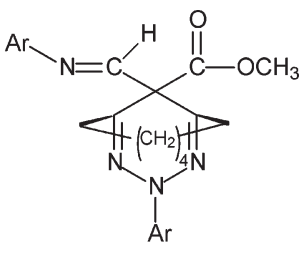

10

Analysis of the emission spectra (Tables 2 and 3) indicate that the $390 \mathrm{~nm}$ absorption band is associated with the emission band centered at approximately $480 \mathrm{~nm}$, whereas the more intense absorption band near $320 \mathrm{~nm}$ is related to the longer wavelength emission at ca. $520 \mathrm{~nm}$. The large Stokes shift of $\sim 120 \mathrm{~nm}$ with $400 \mathrm{~nm}$ excitation, and even larger separation of $\sim 200 \mathrm{~nm}$ with $317 \mathrm{~nm}$ excitation, makes these molecules attractive fluorescent labels for a wide variety of applications. The large separation between excitation and emission enables the use of simple optics and filters. The utility of these molecules as potential biological probes is also derived from the sensitivity of the emission to the local environment as evident from the

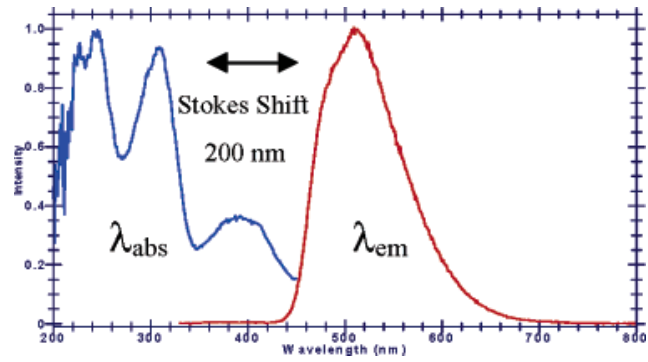

FIGURE 1. Normalized excitation (500 nm emission) and emission (excitation at $317 \mathrm{~nm}$ ) spectra for $\mathbf{3 a}$ in $\mathrm{MeOH}$. Spectra are uncorrected for instrumental effects.
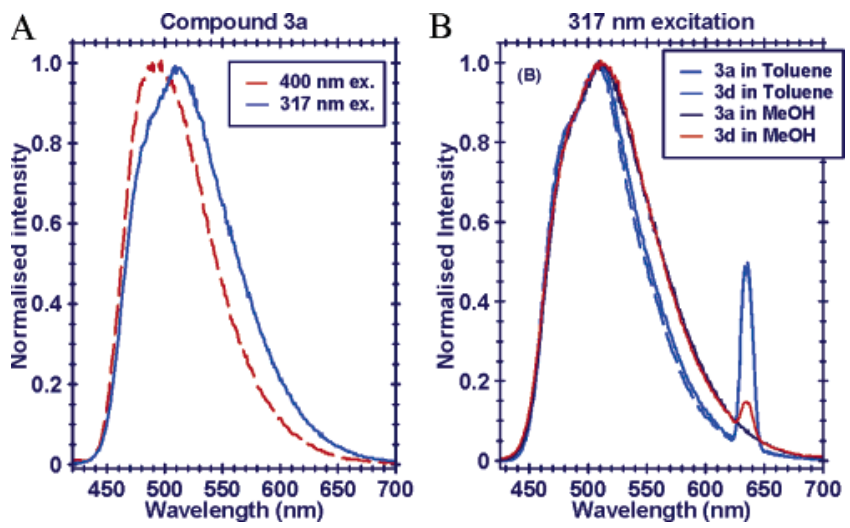

FIGURE 2. (A) Normalized fluorescence emission spectra of 3a, $10^{-6}$ $\mathrm{M}$ in $\mathrm{MeOH}$ using $317 \mathrm{~nm}$ (solid) and $400 \mathrm{~nm}$ (dashed) excitation, showing difference in emission profile; (B) normalized fluorescence emission spectra of $\mathbf{3 a}$ and $\mathbf{3 d}$ in $\mathrm{MeOH}$ and toluene. 
TABLE 3. Steady State Emission Data

\begin{tabular}{|c|c|c|c|c|c|c|c|}
\hline compd & solvent & $\begin{array}{c}\lambda_{\text {em }} \max ^{a} \\
\text { band } 1(\mathrm{~nm})\end{array}$ & $\mathrm{fwhm}^{b}(\mathrm{~nm})$ & $\begin{array}{c}\lambda_{\mathrm{em}} \max ^{a} \\
\text { band } 2(\mathrm{~nm})\end{array}$ & $\mathrm{fwhm}^{b}(\mathrm{~nm})$ & $\begin{array}{c}\text { area ratio } \\
\text { (317 nm ex) }\end{array}$ & $\begin{array}{l}\text { area }^{c} \text { ratio } \\
(400 \mathrm{~nm} \text { ex })\end{array}$ \\
\hline 3a & $\begin{array}{l}\text { MeOH } \\
\text { toluene }\end{array}$ & $\begin{array}{l}483.6 \\
481.1\end{array}$ & $\begin{array}{l}48 \\
43\end{array}$ & $\begin{array}{l}528.7 \\
519.2\end{array}$ & $\begin{array}{l}75 \\
62\end{array}$ & $\begin{array}{l}0.6 \\
0.7\end{array}$ & $\begin{array}{l}1.2 \\
0.9\end{array}$ \\
\hline $3 \mathbf{b}$ & $\begin{array}{l}\mathrm{MeOH} \\
\text { toluene }\end{array}$ & $\begin{array}{l}483.7 \\
481.1\end{array}$ & $\begin{array}{l}48 \\
43\end{array}$ & $\begin{array}{l}528.2 \\
519.3\end{array}$ & $\begin{array}{l}72 \\
62\end{array}$ & $\begin{array}{l}0.6 \\
0.7\end{array}$ & $\begin{array}{l}1.2 \\
0.9\end{array}$ \\
\hline 3c & $\begin{array}{l}\mathrm{MeOH} \\
\text { toluene }\end{array}$ & $\begin{array}{l}482.6 \\
481.7\end{array}$ & $\begin{array}{l}49 \\
43\end{array}$ & $\begin{array}{l}528.1 \\
521.3\end{array}$ & $\begin{array}{l}74 \\
64\end{array}$ & $\begin{array}{l}0.6 \\
0.7\end{array}$ & $\begin{array}{l}1.1 \\
1.0\end{array}$ \\
\hline 3d & $\begin{array}{l}\mathrm{MeOH} \\
\text { toluene }\end{array}$ & $\begin{array}{l}482.8 \\
481.7\end{array}$ & $\begin{array}{l}48 \\
43\end{array}$ & $\begin{array}{l}528.1 \\
521.3\end{array}$ & $\begin{array}{l}76 \\
64\end{array}$ & $\begin{array}{l}0.6 \\
0.7\end{array}$ & $\begin{array}{l}1.1 \\
1.0\end{array}$ \\
\hline $3 \mathbf{e}^{d}$ & $\begin{array}{l}\text { MeOH } \\
\text { toluene }\end{array}$ & $\begin{array}{l}499 \\
498\end{array}$ & $\begin{array}{r}\sim 106 \\
\sim 82\end{array}$ & & & & \\
\hline 7 & $\begin{array}{l}\mathrm{MeOH} \\
\text { toluene }\end{array}$ & $\begin{array}{l}478.9 \\
479.2\end{array}$ & $\begin{array}{l}42 \\
40\end{array}$ & $\begin{array}{l}516.7 \\
516.9\end{array}$ & $\begin{array}{l}58 \\
53\end{array}$ & $\begin{array}{l}1.4 \\
1.7\end{array}$ & $\begin{array}{l}1.5 \\
1.5\end{array}$ \\
\hline
\end{tabular}

${ }^{a}$ Steady-state emission data recorded with $317 \mathrm{~nm}$ excitation at a concentration of $10^{-6} \mathrm{M}$ in $\mathrm{MeOH}$ and toluene. ${ }^{b}$ fwhm, full width at half-maximum. ${ }^{c}$ Area ratio for compounds $3 \mathbf{a}-\mathbf{d}$ and compound 7, recorded with $400 \mathrm{~nm}$ excitation (ex) at a concentration of $10^{-6} \mathrm{M}$ in $\mathrm{MeOH}$ and toluene. ${ }^{d}$ Compound 3e displays a very weak single emission band.

TABLE 4. Fluorescent Lifetime Data for $3 \mathbf{a}^{a}$

\begin{tabular}{cccccccccc}
\hline wavelength & solvent & $\mathrm{A}_{1}(\%)$ & $\tau_{1}$ & $\mathrm{~A}_{2}(\%)$ & $\tau_{2}$ & $\mathrm{~A}_{3}(\%)$ & $\tau_{3}$ & $\chi^{2}$ & $\langle\tau\rangle_{\mathrm{f}}$ \\
\hline 470 & toluene & 30.8 & 9.6 & 69.2 & 3.9 & & & 1.32 & 5.64 \\
520 & toluene & 45.2 & 9.8 & 54.8 & 3.9 & & & 1.31 & 7.85 \\
540 & toluene & 58.2 & 9.5 & 41.8 & 3.8 & & & 1.44 & 8.20 \\
570 & toluene & 76.1 & 9.8 & 23.9 & 4.0 & & & 1.42 & 9.18 \\
470 & $\mathrm{MeOH}$ & 4.3 & 11.2 & 89.3 & 4.0 & 6.4 & 1.1 & 1.34 & 4.09 \\
490 & $\mathrm{MeOH}$ & 16.0 & 10.7 & 78.9 & 4.0 & 5.1 & 0.9 & 1.40 & 4.89 \\
520 & $\mathrm{MeOH}$ & 28.5 & 11.6 & 67.4 & 4.0 & 4.1 & 0.8 & 1.40 & 6.05 \\
540 & $\mathrm{MeOH}$ & 35.6 & 11.8 & 60.6 & 4.0 & 3.8 & 0.8 & 1.46 & 6.65 \\
570 & $\mathrm{MeOH}$ & 42.9 & 12.0 & 53.6 & 4.0 & 3.5 & 0.8 & 1.68 & 7.36
\end{tabular}

${ }^{a}$ Fluorescence lifetime data for compound $\mathbf{3 a}$ in $\mathrm{MeOH}$ and toluene at different emission wavelengths using a $405 \mathrm{~nm}$ excitation source. $\mathrm{A}_{\mathrm{i}}$ represents the fractional intensities, $\tau_{\mathrm{i}}$ represents the individual lifetime components, and $\langle\tau\rangle_{\mathrm{f}}$ is the intensity-averaged lifetime. ${ }^{18}$ The $\chi 2$ (goodness of fit) values are a little high, but this is mostly due to misfits at the beginning of the decay traces and is largely attributed to light scatter and small mismatches between the instrument response and fluorescence decay data.

measurements in different solvents (Table 3). This could be utilized, for example, to study structural changes in macromolecules.

The emission is also sensitive to the solvent environment (Figure 2B) with the emission intensity becoming weaker by a factor of ca. 2 in methanol. The other significant differences are broadening of the emission in methanol compared to toluene and the red shift in the positions of both peaks. For $\mathbf{3 a}-\mathbf{d}$, the longer wavelength emission band is shifted by ca. $10 \mathrm{~nm}$ and broadened by ca. $10 \mathrm{~nm}$ in methanol. Compound 7 does not display this degree of solvent sensitivity with regard to shifting of band positions/shape although the emission intensity is ca. 6-8 times stronger in toluene when compared to methanol.

The fluorescence lifetime behavior of these compounds is complex and is dependent on the emission and excitation wavelengths. Table 4 displays a fluorescence lifetime analysis of compound $\mathbf{3 a}$ in methanol and toluene.

In both cases the intensity averaged lifetime $\langle\tau\rangle_{\mathrm{f}}$ increases on going to longer emission wavelength. This is a consequence of the two emission bands having different lifetimes. In this study of 3a we measured the lifetime of the first band (ca. 480 $\mathrm{nm}$ ) to be $3.9 \pm 0.1 \mathrm{~ns}$ in toluene and only slightly longer, at ca. $4.0 \mathrm{~ns}$, in methanol. The second band (ca. $520 \mathrm{~nm}$ ) in toluene has a lifetime of $9.7 \pm 0.2 \mathrm{~ns}$, but is significantly longer at $11.5 \pm 0.5 \mathrm{~ns}$ in methanol. The source of the third decay component, whose fractional contribution does not vary significantly with emission wavelength, has not yet been identified.

The most interesting point in the lifetime measurements is that the $520 \mathrm{~nm}$ band has a much longer lifetime than the 480 $\mathrm{nm}$ band. This 2-fold to 3-fold difference in lifetimes indicates that the excited state that emits at $520 \mathrm{~nm}$ is significantly more stable than the excited state which emits at $480 \mathrm{~nm}$. The interconversion between the two excited states is dependent on the local environment (Table 4), and this yields a potential lifetime based sensor for solvent polarity and/or hydrogen bonding ability.

The observed fluorescence properties are indicative of excited states involving an interaction between the carbonyl oxygen and the imine unit and may involve a proton transfer. ${ }^{19}$ In the case of 3a the X-ray structure shows that the carbonyl oxygen is close to the hydrogen atom on the imine carbon $\mathrm{C}(24)$. In the case of compound 7 the acidic $5-\mathrm{CH}$ on the triazine ring should readily transfer to the carbonyl oxygen giving an excited-state involving keto-enol tautomerism. A deeper photophysical characterization of these new interesting fluorophores, and in particular the excited-state dynamics, will necessitate further extensive spectroscopic work.

\section{Experimental Section Procedures}

General. Solvents were distilled prior to use and dried by standard methods. $\mathrm{CH}_{2} \mathrm{Cl}_{2}$ and acetone were dried from $\mathrm{CaH}_{2}$ and $\mathrm{KMnO}_{4}$, respectively, and stored over molecular sieves. Proton NMR spectra were measured on a $400 \mathrm{MHz}$ spectrometer (carbon13 spectra at $100 \mathrm{MHz}$ on the same machine) using tetramethylsilane as an internal reference for ${ }^{1} \mathrm{H}$ shifts. Coupling constants, $J$, are reported in Hz. Chemical shifts are given in ppm; multiplicities are indicated by s (singlet), d (doublet), t (triplet), q (quartet), $\mathrm{m}$ (multiplet), and bs (broad signal). NMR spectra were recorded at probe temperature $\left(19 \pm 1^{\circ} \mathrm{C}\right)$ unless otherwise stated. All structural assignments were supported by DEPT, NOEDS, and COSY. For prochiral $\mathrm{CH}_{2}, \mathrm{H}_{\mathrm{A}}$ and $\mathrm{H}_{\mathrm{B}}$ indicate stereochemistry not determined. IR spectra were measured on neat samples. Flash chromatography was performed on $230-400$ mesh silica gel. TLC was performed on $0.25 \mathrm{~mm}$ silica gel $60 \mathrm{~F}_{254}$ plates and visualized by UV (254 $\mathrm{nm})$.

(18) Sillen, A.; Engelberts, Y. Photochem. Photobiol. 1998, 67 (5), 475486.

(19) Moriyama, M.; Kosuge, M.; Tobita, S.; Shizuka, H. Chem. Phys. 2000, 253 (1), 91-103. 
Measurement of Fluorescence Data. For UV-visible absorption data, all optical measurements were made using the nondegassed sample held in $1 \mathrm{~cm}$ path length, Teflon stoppered, quartz cuvettes at room temperature. Fluoresence steady-state emission data were collected on a spectrometer with slit widths set to $5 \mathrm{~nm}$ resolution and a scan speed of $600 \mathrm{~nm} / \mathrm{min}$. Emission data were collected at an excitation wavelength of $317 \mathrm{~nm}$ with a concentration of $10^{-6} \mathrm{M}$ in spectroscopic grade methanol or toluene. Excitation spectra were collected at emissions of 470 and $520 \mathrm{~nm}$ using the same instrumental settings. The emission spectra were deconvoluted by fitting log-normal functions using the GRAMS-AI software package. Spectra are not corrected for instrument response. The fluoresence lifetime data were collected on a lifetime spectrometer using a $405 \mathrm{~nm}$ laser diode excitation source. Fluoresence lifetimes were obtained by deconvolution of the decay data using the fluofit program.

General Procedure for the Synthesis of 1a, 2a, and 4a. A suspension of 1,2-bis(phenyl)hydrazone of benzil (1 g, $2.56 \mathrm{mmol}$ ) in dichloromethane $(25 \mathrm{~mL})$ was treated with lead dioxide $(0.73 \mathrm{~g}$, $3.07 \mathrm{mmol}$ ) and stirred for $18 \mathrm{~h}$ at ambient temperature. Insoluble salts were removed and washed thoroughly with dichloromethane. Evaporation of the combined mother liquor and washings gave 1a (80\%): mp $178-179{ }^{\circ} \mathrm{C}$ (from toluene-petroleum spirit bp 60-80 $\left.{ }^{\circ} \mathrm{C}\right) .{ }^{20}$ The following substrates were similarly prepared and purified; 1b (mp 205-207 $\left.{ }^{\circ} \mathrm{C}, 82 \%\right)$, 1c (mp 197-199 $\left.{ }^{\circ} \mathrm{C}, 88 \%\right),{ }^{20} \mathbf{1 d}(\mathrm{mp}$ 187-188 $\left.{ }^{\circ} \mathrm{C}, 65 \%\right)$, $1 \mathbf{e}\left(\mathrm{mp} 180-182{ }^{\circ} \mathrm{C}\right.$, (from $\left.\left.\mathrm{Et}_{2} \mathrm{O}\right) 73 \%\right) .{ }^{20}$

Synthesis of 5-Ethoxycarbonyl-5-( $N$-phenylformimidoyl)2,4,6-triphenyl-2,5-dihydro-1,2,3-triazine 2a. A suspension of 2,4,5-triphenyl-1,2,3-triazolium-1-phenyl aminide 1a (0.3 g, 0.77 $\mathrm{mmol})$ in dry acetone $\left(10 \mathrm{~cm}^{3}\right)$ was treated with an excess of methyl propiolate $\left(0.14 \mathrm{~cm}^{3}, 1.57 \mathrm{mmol}\right)$. The reaction mixture was stirred under reflux for $24 \mathrm{~h}$ after which time the solvent was removed under reduced pressure. The residue (in $2 \mathrm{~cm}^{3}$ of methylene chloride) was placed on a silica gel column (230-400 mesh ASTM). The column was eluted with a gradient mixture (1:0 to $0: 1$ ) (v/v) of petroleum spirit (bp $40-60{ }^{\circ} \mathrm{C}$ )/methylene chloride, using a $2.5 \%(\mathrm{v} / \mathrm{v})$ changing gradient, to give the product $2 \mathrm{a}$ as a yellow solid (52\%): mp $122-123{ }^{\circ} \mathrm{C}$ (from ethanol). ${ }^{1} \mathrm{H}$ NMR $\left(400 \mathrm{MHz} \mathrm{CDCl}_{3}\right): \delta 0.87\left(\mathrm{t}, \mathrm{CO}_{2} \mathrm{CH}_{2} \mathrm{CH}_{3}, 3 \mathrm{H}\right.$ ), $4.0\left(\mathrm{q}, \mathrm{CO}_{2} \mathrm{CH}_{2-}\right.$ $\mathrm{CH}_{3}, 2 \mathrm{H}$ ), 6.93-6.95 (d, $J=7.7 \mathrm{~Hz}, 2 \mathrm{H} \mathrm{H}$ ortho iminyl-N-Ph), 7.18-7.49 (m, 10H, Ar-H), 7.86-7.89 (m, 4H, Ar-H), 8.0-8.02 (d, $J=7.7 \mathrm{~Hz}, 2 \mathrm{H}$, aromatics), $8.51(1 \mathrm{H}, \mathrm{s},-\mathrm{N}=\mathrm{CH}) .{ }^{13} \mathrm{C} \mathrm{NMR}$ $\left(\mathrm{CDCl}_{3}\right): \delta 13.5\left(\mathrm{CO}_{2} \mathrm{CH}_{2} \mathrm{CH}_{3}\right), 53.7(\mathrm{C}-5), 62.5\left(\mathrm{CO}_{2} \mathrm{CH}_{2} \mathrm{CH}_{3}\right)$, 135.0 (C-6), 135.4 (C-4), 145.4, 116.2, 128.7, 123.7 (C-1', C-2', C-3', C-4' respectively, 2-N-Ph), 151.1, 120.5, 129.6, 126.3 (C1', C-2', C-3', C-4' respectively, iminyl-N-Ph), 129.0, 129.1 (remaining aromatics), $159.9(-\mathrm{N}=\mathrm{CH}), 169.7(\mathrm{C}=\mathrm{O}) . \mathrm{IR}(\mathrm{NaCl})$ $v \mathrm{~cm}^{-1}$ : $1729.6(\mathrm{C}=\mathrm{O}), 1598.1(\mathrm{C}=\mathrm{N})$. Anal. Calcd for $\mathrm{C}_{31} \mathrm{H}_{26} \mathrm{~N}_{4} \mathrm{O}_{2}$ : C, 76.5; H, 5.3; N, 11.5. Found: C, 76.1; H, 5.0; N, 11.3.

6-Ethoxycarbonyl-2,3a,4,6a-tetraphenyl-3,3a,4,6a-tetrahydropyrrolo[2,3-d]-[1,2,3]-triazol-2-ium-3-ide 4a. Compound 4a, a second product, was isolated subsequently from the column as a yellow solid (8\%): mp $186-187^{\circ} \mathrm{C}$ (from ethanol). ${ }^{1} \mathrm{H}$ NMR (400 $\left.\mathrm{MHz} \mathrm{CDCl}_{3}\right): \delta 1.12\left(\mathrm{t}, 3 \mathrm{H}, \mathrm{CO}_{2} \mathrm{CH}_{2} \mathrm{CH}_{3}\right), 4.03-4.08(\mathrm{~m}, 1 \mathrm{H}$, $\mathrm{H}_{\mathrm{A}}$ of $\left.\mathrm{CH}_{2}\right), 4.18-4.23\left(\mathrm{~m}, 1 \mathrm{H}, \mathrm{H}_{\mathrm{B}}\right.$ of $\left.\mathrm{CH}_{2}\right), 6.92-6.98(\mathrm{~m}, 10 \mathrm{H}$, $\mathrm{Ar}-\mathrm{H}$ ), $7.1-7.2$ (m, 4H, aromatics), 7.5-7.6 (m, 4H, aromatics), $8.40(\mathrm{~s}, 1 \mathrm{H}, 5-\mathrm{CH}), 8.42-8.44\left(\mathrm{~m}, 2 \mathrm{H}\right.$, aromatics). ${ }^{13} \mathrm{C} \mathrm{NMR}$ $\left(\mathrm{CDCl}_{3}\right): \delta 14.5\left(\mathrm{CO}_{2} \mathrm{CH}_{2} \mathrm{CH}_{3}\right), 59.6\left(\mathrm{CO}_{2} \mathbf{C H}_{2} \mathrm{CH}_{3}\right), 93.0(\mathrm{C}-6 \mathrm{a})$, 105.7 (C-3a), 107.6 (C-6), 135.9 (C-1', 6a-Ph), 137.7 (C-1', 3аPh), 140.6, 123.2, 126.8, 129.0 (C-1', C-2', C-3', C-4', respectively, 2-N-Phenyl), 139.3, 118.1, 127.5, 129.1 (C-1', C-2', C-3', C-4', respectively, 4-N-Ar), 148.6 (C-5), 131.9, 127.7, 127.5 (remaining aromatics), $165.0(\mathrm{C}=\mathrm{O})$. IR (neat, $\left.\mathrm{cm}^{-1}\right)$ : $1705(\mathrm{C}=0)$. Anal. Calcd for $\mathrm{C}_{31} \mathrm{H}_{26} \mathrm{~N}_{4} \mathrm{O}_{2}$ : C, 76.5; H, 5.4; N, 11.5. Found: C, 76.6; $\mathrm{H}, 5.5 ; \mathrm{N}, 11.8$. The remaining eluents were intractable resins.

(20) Butler, R. N.; Gillan, A. M.; Collier, S.; James, J. P. J. Chem. Res. Synop. 1987, 332-333.
The following products were synthesized using similar experimental conditions.

5-Ethoxycarbonyl-5-( $N$-p-methoxyphenylformimidoyl)-2-pmethoxyphenyl-4,6-diphenyl-2,5-dihydro-1,2,3-triazine $2 \mathrm{~b}$. Compound $\mathbf{2 b}$ was isolated as a yellow solid which fluoresced intensely when exposed to UV light (52\%): $\mathrm{mp} 140-141^{\circ} \mathrm{C}$ (from ethanol). ${ }^{1} \mathrm{H}$ NMR (400 MHz CDCl ${ }_{3}$ ): $\delta 0.81$ (t, $3 \mathrm{H}, \mathrm{CO}_{2} \mathrm{CH}_{2} \mathrm{CH}_{3}$ ), 3.75 (s, $3 \mathrm{H}$, iminyl $\left.\mathrm{N}-\mathrm{C}_{6} \mathrm{H}_{4}-\mathrm{OCH}_{3}-p\right), 3.83\left(\mathrm{~s}, 3 \mathrm{H}, 2-\mathrm{N}-\mathrm{C}_{6} \mathrm{H}_{4}-\mathrm{OCH}_{3}-\right.$ p), 3.94 (q, 2H, $\mathrm{CO}_{2} \mathrm{CH}_{2} \mathrm{CH}_{3}$ ), 6.78-6.80 (d), 6.89-6.91 (d), (iminyl $\mathrm{N}-\mathrm{C}_{6} \mathrm{H}_{4}-\mathrm{OCH}_{3}-p, \mathrm{AA}^{\prime} \mathrm{BB}^{\prime} J_{\mathrm{AB}} 8.7 \mathrm{~Hz}$ ), 6.94-6.96 (d), $7.81-7.83$ (d), (2-N- $\left.\mathrm{C}_{6} \mathrm{H}_{4}-\mathrm{OCH}_{3}-p, \mathrm{AA}^{\prime} \mathrm{BB}^{\prime} J_{\mathrm{AB}} 9 \mathrm{~Hz}\right), 7.36-$ 7.38 (m, 4H, aromatics), 7.75-7.76 (m, 6H, aromatics), $8.4(\mathrm{~s}, 1 \mathrm{H}$, $-\mathrm{N}=\mathrm{CH}) .{ }^{13} \mathrm{C}$ NMR $\left(\mathrm{CDCl}_{3}\right): 13.4\left(\mathrm{CO}_{2} \mathrm{CH}_{2} \mathrm{CH}_{3}\right), 54.1(\mathrm{C}-5)$, 55.5 and $55.7\left(\mathrm{OCH}_{3}\right.$ of iminyl- $\mathrm{N}-\mathrm{C}_{6} \mathrm{H}_{4}-\mathrm{OCH}_{3}-p$ and $\mathrm{OCH}_{3}$ of 2-N- $\left.\mathrm{C}_{6} \mathrm{H}_{4}-\mathrm{OCH}_{3}-p\right), 62.6\left(\mathrm{CO}_{2} \mathrm{CH}_{2} \mathrm{CH}_{3}\right), 143.9,122.0,117.4$, 158.5 (C-1', C-2', C-3', C-4', respectively, iminyl- $\mathrm{N}-\mathrm{C}_{6} \mathrm{H}_{4}-\mathrm{OCH}_{3}-$ p), 139.4, 129.3, 114.1, 156.1 (C-1', C-2', C-3', C-4', respectively, $\left.2-\mathrm{N}-\mathrm{C}_{6} \mathrm{H}_{4}-\mathrm{OCH}_{3}-p\right), 134.1$, (C-6), 135.1 (C-4), $157.7(-\mathrm{N}=\mathrm{CH})$, $169.8(\mathrm{C}=\mathrm{O})$. IR (neat, $\left.\mathrm{cm}^{-1}\right)$ : $1728(\mathrm{C}=\mathrm{O}), 1598(\mathrm{C}=\mathrm{N})$. Anal. Calcd for $\mathrm{C}_{33} \mathrm{H}_{30} \mathrm{~N}_{4} \mathrm{O}_{4}$ : C, 72.5; $\mathrm{H}, 5.5 ; \mathrm{N}, 10.2$. Found: C, 72.1; H, 5.3; N, 10.5 .

5-Ethoxycarbonyl-5-( $N$-p-bromophenylformimidoyl)-4,6-diphenyl-2-p-bromo-2,5-dihydro-1,2,3-triazine 2c. Compound 2c was isolated as a solid with intense yellow color (35\%): mp 193$194{ }^{\circ} \mathrm{C}$ (from ethanol). ${ }^{1} \mathrm{H}$ NMR $\left(400 \mathrm{MHz} \mathrm{CDCl}_{3}\right): \delta 0.78(\mathrm{t}$, $3 \mathrm{H}, \mathrm{CO}_{2} \mathrm{CH}_{2} \mathrm{CH}_{3}$ ), 3.93 (q, $2 \mathrm{H}, \mathrm{CO}_{2} \mathrm{CH}_{2} \mathrm{CH}_{3}$ ), 6.68-6.70 (d), $7.35-7.37$ (d), (iminyl $\mathrm{N}-\mathrm{C}_{6} \mathrm{H}_{4}-\mathrm{Br}-p$, $\mathrm{AA}^{\prime} \mathrm{BB}^{\prime} J_{\mathrm{AB}} 8.7 \mathrm{~Hz}$ ), 7.387.40 (m, 6H, aromatic), 7.47-7.50 (d), 7.75-7.78 (d), (2-N- $\mathrm{C}_{6} \mathrm{H}_{4}-$ $\mathrm{Br}-p, \mathrm{AA}^{\prime} \mathrm{BB}^{\prime} J_{\mathrm{AB}} 9.2 \mathrm{~Hz}$ ), 7.71-7.78 (m, 4H, aromatic), 8.52 (s, $1 \mathrm{H}-\mathrm{N}=\mathrm{CH}) .{ }^{13} \mathrm{C} \mathrm{NMR}\left(\mathrm{CDCl}_{3}\right): \delta 13.3\left(\mathrm{CO}_{2} \mathrm{CH}_{2} \mathrm{CH}_{3}\right), 53.6(\mathrm{C}-$ 5), $62.5\left(\mathrm{CO}_{2} \mathrm{CH}_{2} \mathrm{CH}_{3}\right), 134.7$ (C-6), 135.9 (C-4), 144.2, 117.6, 128.5, $116.4\left(\mathrm{C}-1^{\prime}, \mathrm{C}-2^{\prime}, \mathrm{C}-3^{\prime}\right.$, C-4', respectively, 2- $\mathrm{N}-\mathrm{C}_{6} \mathrm{H}_{4}-\mathrm{Br}-$ p), 149.8, 122.1, 129.7, 120.0 (C-1', C-2', C-3', C-4', respectively, iminyl $\left.-\mathrm{N}-\mathrm{C}_{6} \mathrm{H}_{4}-\mathrm{Br}-p\right)$ ), 128.4, 132.1, 131.8 (remaining aromatics), $160.3(-\mathrm{N}=\mathrm{CH}), 169.3(\mathrm{C}=\mathrm{O})$. Anal. Calcd for $\mathrm{C}_{31} \mathrm{H}_{24^{-}}$ $\mathrm{Br}_{2} \mathrm{~N}_{4} \mathrm{O}_{2}$ : C, 57.7; H, 3.7; N, 8.7. Found: C, 57.9; H, 3.8; N, 8.5.

5-Ethoxycarbonyl-5-( $N$-p-chlorophenylformimidoyl)-2-p-chlorophenyl-4,6-diphenyl-2,5-dihydro-1,2,3-triazine 2d. Compound 2d was isolated as a solid with intense yellow color (45\%): $\mathrm{mp}$ $179-180{ }^{\circ} \mathrm{C}$ (from ethanol). ${ }^{1} \mathrm{H}$ NMR (400 $\left.\mathrm{MHz} \mathrm{CDCl}_{3}\right): \delta 0.78$ (t, $\mathrm{CO}_{2} \mathrm{CH}_{2} \mathrm{CH}_{3}, 3 \mathrm{H}$ ), 3.93 (q, $\left.\mathrm{CO}_{2} \mathrm{CH}_{2} \mathrm{CH}_{3}, 2 \mathrm{H}\right), 6.78-6.81$ (d), 7.22-7.24 (d), (iminyl-N- $\mathrm{C}_{6} \mathrm{H}_{4}-\mathrm{Cl}-p, \mathrm{AA}^{\prime} \mathrm{BB}^{\prime} J_{\mathrm{AB}} 8.7 \mathrm{~Hz}$ ), 7.357.38 (d), $7.84-7.87$ (d), (2-N- $\left.\mathrm{C}_{6} \mathrm{H}_{4}-\mathrm{Cl}-p, \mathrm{AA}^{\prime} \mathrm{BB}^{\prime} J_{\mathrm{AB}} 9.1 \mathrm{~Hz}\right)$, 7.41-7.42 (m, 6H, aromatic), 7.72-7.73 (m, 4H, aromatic), 8.53 (s, $1 \mathrm{H}-\mathrm{N}=\mathrm{CH}) .{ }^{13} \mathrm{C} \mathrm{NMR}\left(\mathrm{CDCl}_{3}\right): \delta 13.4\left(\mathrm{CO}_{2} \mathrm{CH}_{2} \mathrm{CH}_{3}\right), 53.6$ (C-5), $61.9\left(\mathrm{CO}_{2} \mathrm{CH}_{2} \mathrm{CH}_{3}\right), 134.7$ (C-6), 135.9 (C-4), 149.4, 121.7, 129.2, 132.1 (C-1', C-2', C-3', C-4', respectively, iminyl $-\mathrm{N}-$ $\mathrm{C}_{6} \mathrm{H}_{4}-\mathrm{Cl}-p$ ), 144.6, 117.2, 129.7, 128.7 (C-1', C-2', C-3', C-4', respectively, 2-N- $\mathrm{C}_{6} \mathrm{H}_{4}-\mathrm{Cl}-p$ ), 128.9, 128.7, 128.5 (remaining aromatics), $159.7(-\mathrm{N}=\mathrm{CH}), 169.7(\mathrm{C}=\mathrm{O})$. Anal. Calcd for $\mathrm{C}_{31} \mathrm{H}_{24^{-}}$ $\mathrm{Cl}_{2} \mathrm{~N}_{4} \mathrm{O}_{2}$ : C, 67.0; H, 4.3; N, 10.0. Found: C, 66.7; H, 4.4; N, 10.1 .

5-Ethoxycarbonyl-5-(N-p-nitrophenylformimidoyl)-2-p-nitrophenyl-4,6-diphenyl-2,5-dihydro-1,2,3-triazine 2e. Compound $2 \mathrm{e}$ was isolated as a solid with an intense yellow color (38\%): $\mathrm{mp}$ $165-167{ }^{\circ} \mathrm{C}$ (from ethanol). ${ }^{1} \mathrm{H}$ NMR (400 $\left.\mathrm{MHz} \mathrm{CDCl}_{3}\right): \delta 0.80$ (t, $3 \mathrm{H}, \mathrm{CO}_{2} \mathrm{CH}_{2} \mathrm{CH}_{3}$ ), 3.98 (q, $2 \mathrm{H}, \mathrm{CO}_{2} \mathrm{CH}_{2} \mathrm{CH}_{3}$ ), 6.76-6.79 (d), 8.03-8.06 (d), (iminyl- $\mathrm{N}-\mathrm{C}_{6} \mathrm{H}_{4}-\mathrm{NO}_{2}-p$, $\mathrm{AA}^{\prime} \mathrm{BB}^{\prime} J_{\mathrm{AB}} 8.9 \mathrm{~Hz}$ ), $7.93-7.95$ (d), $8.20-8.22$ (d), $\left(2-\mathrm{N}-\mathrm{C}_{6} \mathrm{H}_{4}-\mathrm{NO}_{2}-p, \mathrm{AA}^{\prime} \mathrm{BB}^{\prime} J_{\mathrm{AB}}\right.$ $9.4 \mathrm{~Hz}), 7.36-7.41(\mathrm{~m}, 6 \mathrm{H}$, aromatics), 7.71-7.73 (m, $4 \mathrm{H}$, aromatics), $8.73(\mathrm{~s}, 1 \mathrm{H},-\mathrm{N}=\mathrm{CH}) .{ }^{13} \mathrm{C} \mathrm{NMR}\left(\mathrm{CDCl}_{3}\right): 13.3\left(\mathrm{CO}_{2^{-}}\right.$ $\mathrm{CH}_{2} \mathrm{CH}_{3}$ ), 53.2 (C-5), $63.1\left(\mathrm{CO}_{2} \mathrm{CH}_{2} \mathrm{CH}_{3}\right), 134.1$ (C-6), 138.3 (C4), 149.1, 115.5, 124.9, 143.4 (C-1', C-2', C-3', C-4', respectively, $\left.2-\mathrm{N}-\mathrm{C}_{6} \mathrm{H}_{4}-\mathrm{NO}_{2}-p\right), 156.2,120.6,125.3,145.9$, (C-1', C-2', C-3', C-4', respectively, iminyl- $\left.\mathrm{N}-\mathrm{C}_{6} \mathrm{H}_{4}-\mathrm{NO}_{2}-p\right), 128.2,128.8,130.4$ (remaining aromatics), $162.9(-\mathrm{N}=\mathrm{CH}), 168.7(\mathrm{C}=\mathrm{O})$. Anal. Calcd for $\mathrm{C}_{31} \mathrm{H}_{24} \mathrm{~N}_{6} \mathrm{O}_{6}$ : C, 64.5; $\mathrm{H}, 4.1 ; \mathrm{N}, 14.5$. Found: C, 64.3; H, 4.0; $\mathrm{N}, 14.5$. 
6-Ethoxycarbonyl-3a,6a-diphenyl-2,4-bis(p-bromophenyl)3,3a,4,6a-tetrahydropyrrolo[2,3-d][1,2,3]triazol-2-ium-3-ide 4c. Compound 4c was isolated as a yellow solid (23\%): mp 157-158 ${ }^{\circ} \mathrm{C}$ (from ethanol). ${ }^{1} \mathrm{H}$ NMR (400 $\mathrm{MHz} \mathrm{CDCl}_{3}$ ): $\delta 1.13$ (t, $3 \mathrm{H}$, $\left.\mathrm{CO}_{2} \mathrm{CH}_{2} \mathrm{CH}_{3}\right), 4.03-4.11\left(\mathrm{~m}, 1 \mathrm{H}, \mathrm{H}_{\mathrm{A}}\right.$ of $\left.\mathrm{CO}_{2} \mathrm{CH}_{2} \mathrm{CH}_{3}\right), 4.16-4.24$ (m, $1 \mathrm{H}, \mathrm{H}_{\mathrm{B}}$ of $\mathrm{CO}_{2} \mathrm{CH}_{2} \mathrm{CH}_{3}$ ), 6.89-7.0 (m, $5 \mathrm{H}$, aromatics), 7.087.10 (d), 7.65-7.68 (d), (4-N- $\left.\mathrm{C}_{6} \mathrm{H}_{4}-\mathrm{Br}-p, \mathrm{AA}^{\prime} \mathrm{BB}^{\prime} J_{\mathrm{AB}} 8.9 \mathrm{~Hz}\right)$, $7.25-7.28$ (d), 8.31-8.33 (d), (2-N- $\mathrm{C}_{6} \mathrm{H}_{4}-\mathrm{Br}-p, \mathrm{AA}^{\prime} \mathrm{BB}^{\prime} J_{\mathrm{AB}} 8.9$ $\mathrm{Hz}$ ), 6.89-7.0 (m, 10H, aromatics), 8.33 (s, 1H, 5-CH). ${ }^{13} \mathrm{C}$ NMR $\left(\mathrm{CDCl}_{3}\right): \delta 14.4\left(\mathrm{CO}_{2} \mathrm{CH}_{2} \mathrm{CH}_{3}\right), 59.8\left(\mathrm{CO}_{2} \mathrm{CH}_{2} \mathrm{CH}_{3}\right), 93.1(\mathrm{C}-6 \mathrm{a})$, 105.5 (C-3a), 108.5 (C-6), 135.3 (C-1', 6a-Ph), 137.2 (C-1', 3a$\mathrm{Ph}), 139.3,124.7,132.2,126.4$ (C-1', C-2', C-3', C-4', respectively, 2-N- $\left.\mathrm{C}_{6} \mathrm{H}_{4}-\mathrm{Br}-p\right)$, 138.4, 119.5, 132.1, 115.4 (C-1', C-2', C-3', $\mathrm{C}-4^{\prime}$, respectively, 4- $\mathrm{N}-\mathrm{C}_{6} \mathrm{H}_{4}-\mathrm{Br}-p$ ), 127.1, 127.6, 127.8 (remaining aromatics), $147.9(\mathrm{C}-5), 164.7(\mathrm{C}=\mathrm{O})$. IR (neat, $\left.\mathrm{cm}^{-1}\right): 1705$ $(\mathrm{C}=\mathrm{O})$. Anal. Calcd for $\mathrm{C}_{31} \mathrm{H}_{24} \mathrm{Br}_{2} \mathrm{~N}_{4} \mathrm{O}_{2}$ : C, 57.8; $\mathrm{H}, 3.7$; N, 8.7. Found: $\mathrm{C}, 57.7 ; \mathrm{H}, 3.9$; N, 8.4.

6-Ethoxycarbonyl-3a,6a-diphenyl-2,4-bis(p-chlorophenyl)3,3a,4,6a-tetrahydropyrrolo[2,3-d][1,2,3]triazol-2-ium-3-ide 4d. Compound 4d was isolated as a yellow solid (27\%): mp 174$175{ }^{\circ} \mathrm{C}$ (from ethanol). ${ }^{1} \mathrm{H}$ NMR $\left(400 \mathrm{MHz} \mathrm{CDCl}_{3}\right.$ ): $\delta 1.13$ (t, $\left.\mathrm{CO}_{2} \mathrm{CH}_{2} \mathrm{CH}_{3}, 3 \mathrm{H}\right), 4.05-4.11\left(\mathrm{~m}, 1 \mathrm{H}, \mathrm{H}_{\mathrm{A}}\right.$ of $\left.\mathrm{CO}_{2} \mathrm{CH}_{2} \mathrm{CH}_{3}\right), 4.17-$ $4.23\left(\mathrm{~m}, 1 \mathrm{H}, \mathrm{H}_{\mathrm{B}}\right.$ of $\left.\mathrm{CO}_{2} \mathrm{CH}_{2} \mathrm{CH}_{3}\right), 6.89-7.00$ (m, 8H, aromatic), 7.11-7.14 (m, 6H, aromatic), 7.50-7.52 (d), 8.38-8.41 (d), (2$\mathrm{N}-\mathrm{C}_{6} \mathrm{H}_{4}-\mathrm{Cl}-p$, $\left.\mathrm{AA}^{\prime} \mathrm{BB}^{\prime} J_{\mathrm{AB}} 9.1 \mathrm{~Hz}\right), 8.33$ (s, $\left.1 \mathrm{H}, 5-\mathrm{CH}\right) .{ }^{13} \mathrm{C}$ NMR $\left(\mathrm{CDCl}_{3}\right): \delta 14.4\left(\mathrm{CO}_{2} \mathrm{CH}_{2} \mathrm{CH}_{3}\right), 59.7\left(\mathrm{CO}_{2} \mathrm{CH}_{2} \mathrm{CH}_{3}\right), 93.1(\mathrm{C}-6 \mathrm{a})$, 105.6 (C-3a), 108.4 (C-6), 135.4 (C-1', 6a-Ph), 137.3 (C-1', 3a$\mathrm{Ph}), 138.9,124.5,127.6,137.9$ (C-1', C-2', C-3', C-4', respectively, $\left.2-\mathrm{N}-\mathrm{C}_{6} \mathrm{H}_{4}-\mathrm{Cl}-p\right)$, 138.1, 119.1, 129.2, 127.0, (C-1', C-2', C-3', $\mathrm{C}-4^{\prime}$, respectively, $4-\mathrm{N}-\mathrm{C}_{6} \mathrm{H}_{4}-\mathrm{Cl}-p$ ), 127.8 (remaining aromatic) 148.0 (C-5), $164.7(\mathrm{C}=\mathrm{O})$. Anal. Calcd for $\mathrm{C}_{31} \mathrm{H}_{24} \mathrm{Cl}_{2} \mathrm{~N}_{4} \mathrm{O}_{2}$ : C, 67.05; H, 4.3; N, 10.0. Found: C, 66.75; H, 4.4; N, 9.9.

6-Ethoxycarbonyl-3a,6a-diphenyl-2,4-bis(p-nitrophenyl)3,3a,4,6a-tetrahydropyrrolo[2,3-d][1,2,3]triazol-2-ium-3-ide 4e. Compound 4e was isolated as a yellow solid (33\%): mp 172-174 ${ }^{\circ} \mathrm{C}$ (from ethanol). ${ }^{1} \mathrm{H}$ NMR (400 $\left.\mathrm{MHz} \mathrm{CDCl}_{3}\right): \delta 1.15$ (t, 3H, $\mathrm{CO}_{2} \mathrm{CH}_{2} \mathrm{CH}_{3}$ ), $4.09-4.15$ (m, $1 \mathrm{H}, \mathrm{H}_{\mathrm{A}}$ of $\left.\mathrm{CO}_{2} \mathrm{CH}_{2} \mathrm{CH}_{3}\right), 4.18-4.25$ (m, $1 \mathrm{H}, \mathrm{H}_{\mathrm{B}}$ of $\mathrm{CO}_{2} \mathrm{CH}_{2} \mathrm{CH}_{3}$ ), 6.90-6.92 (m, 4H, aromatic), 6.977.02 (m, 6H, aromatic), 7.23-7.26 (d), 8.05-8.07 (d), (4-N- $\mathrm{C}_{6} \mathrm{H}_{4}-$ $\left.\mathrm{NO}_{2}-p, \mathrm{AA}^{\prime} \mathrm{BB}^{\prime} J_{\mathrm{AB}} 9.4 \mathrm{~Hz}\right), 8.40-8.42$ (d), 8.65-8.67 (d), (2$\mathrm{N}-\mathrm{C}_{6} \mathrm{H}_{4}-\mathrm{NO}_{2}-p, \mathrm{AA}^{\prime} \mathrm{BB}^{\prime} J_{\mathrm{AB}} 9.1 \mathrm{~Hz}$ ), 8.44 (s, $\left.1 \mathrm{H}, 5-\mathrm{CH}\right) .{ }^{13} \mathrm{C}$ NMR $\left(\mathrm{CDCl}_{3}\right): \delta 14.4\left(\mathrm{CO}_{2} \mathrm{CH}_{2} \mathrm{CH}_{3}\right), 60.4\left(\mathrm{CO}_{2} \mathrm{CH}_{2} \mathrm{CH}_{3}\right), 93.2$ (C-6a), 105.6 (C-3a), 112.2 (C-6), 134.5 (C-1', 6a-Ph), 136.3 (C1', 3a-Ph), 144.0, 124.5, 125.4, 146.3 (C-1', C-2', C-3', C-4', respectively, 2- $\left.\mathrm{N}-\mathrm{C}_{6} \mathrm{H}_{4}-\mathrm{NO}_{2}-p\right), 144.4,117.0,124.4,142.0$ (C$1^{\prime}, \mathrm{C}-2^{\prime}$, C-3', C-4', respectively, 4- $\mathrm{N}-\mathrm{C}_{6} \mathrm{H}_{4}-\mathrm{NO}_{2}-p$ ), 127.8, 128.2, 128.4 (remaining aromatics), $150.3(\mathrm{C}-5), 164.0(\mathrm{C}=\mathrm{O})$. Anal. Calcd for $\mathrm{C}_{31} \mathrm{H}_{24} \mathrm{~N}_{6} \mathrm{O}_{6}$ : C, 64.5; $\mathrm{H}, 4.1$; N, 14.6. Found: C, 64.8; H, 3.9; N, 14.7.

5-Methoxycarbonyl-5-( $N$-phenylformimidoyl)-2,4,6-triphenyl2,5-dihydro-1,2,3-triazine 3a. Compound 3a was isolated as a yellow solid which fluoresced intensely when exposed to UV light (38\%): mp $146-147{ }^{\circ} \mathrm{C}$ (from ethanol). ${ }^{1} \mathrm{H}$ NMR (400 MHz $\left.\mathrm{CDCl}_{3}\right): \delta 3.54\left(\mathrm{~s}, 3 \mathrm{H}, \mathrm{OCH}_{3}\right), 6.77-6.79(\mathrm{~d}, J=8.3 \mathrm{~Hz}, 2 \mathrm{H}$, $\mathrm{H}_{\text {ortho }}$ 4-N-phenyl ring), 7.11-7.42 (m, $12 \mathrm{H}$, aromatic), 7.76-7.92 (m, 6H, aromatic), $8.47(\mathrm{~s}, 1 \mathrm{H},-\mathrm{N}=\mathrm{CH}) .{ }^{13} \mathrm{C} \mathrm{NMR}\left(\mathrm{CDCl}_{3}\right): \delta$ 53.6 (- $\left.\mathrm{OCH}_{3}\right), 53.7$ (C-5), 134.9 (C-6), 135.3 (C-4), 150.0, 120.3, 129.5, 126.3 (C-1', C-2', C-3', C-4', respectively, iminyl-N-phenyl ring), 145.4, 116.1, 128.9, 123.6 (C-1', C-2', C-3', C-4', respectively, 2-N-phenyl ring), $160.5(-\mathrm{N}=\mathrm{CH}), 170.2(\mathrm{C}=\mathrm{O}) . \quad$ IR $(\mathrm{NaCl})$ $v \mathrm{~cm}^{-1}: 1739.9(\mathrm{C}=\mathrm{O}), 1598.8(\mathrm{C}=\mathrm{N})$. Anal. Calcd for $\mathrm{C}_{30} \mathrm{H}_{24} \mathrm{~N}_{4} \mathrm{O}_{2}$ : C, 76.3; H, 5.1; N, 11.9. Found: C, 76.3; H, 4.8; N, 11.6.

5-Methoxycarbonyl-5-( $N$-p-methoxyphenylformimidoyl)-4,6diphenyl-2,5-dihydro-1,2,3-triazine $3 \mathbf{b}$. Compound $3 \mathbf{b}$ was isolated as a solid with intense yellow color (33\%): mp $144-145^{\circ} \mathrm{C}$ (from ethanol). ${ }^{1} \mathrm{H}$ NMR (400 MHz $\mathrm{CDCl}_{3}$ ): $\delta 3.53$ (s, 3H, $\mathrm{CO}_{2^{-}}$ $\left.\mathrm{CH}_{3}\right), 3.74(\mathrm{~s}, 3 \mathrm{H}), 3.82(\mathrm{~s}, 3 \mathrm{H}),\left(2-\mathrm{N}-\mathrm{C}_{6} \mathrm{H}_{4}-\mathrm{OCH}_{3}-p\right.$ and iminyl$\mathrm{N}-\mathrm{C}_{6} \mathrm{H}_{4}-\mathrm{OCH}_{3}-p$ ), 6.77-6.79 (d), 6.86-6.88 (d), (iminyl-N-
$\left.\mathrm{C}_{6} \mathrm{H}_{4}-\mathrm{OCH}_{3}-p, \mathrm{AA}^{\prime} \mathrm{BB}^{\prime} J_{\mathrm{AB}} 8.7 \mathrm{~Hz}\right), 6.95-6.97$ (d), 7.83-7.86 (d), (2-N- $\left.\mathrm{C}_{6} \mathrm{H}_{4}-\mathrm{OCH}_{3}-p, \mathrm{AA}^{\prime} \mathrm{BB}^{\prime} J_{\mathrm{AB}} 9.1 \mathrm{~Hz}\right), 7.36-7.38(\mathrm{~m}, 6 \mathrm{H}$, aromatics), $7.78-7.80$ (m, $4 \mathrm{H}$, aromatics), $8.39(\mathrm{~s}, 1 \mathrm{H},-\mathrm{N}=\mathrm{CH})$. ${ }^{13} \mathrm{C}$ NMR $\left(\mathrm{CDCl}_{3}\right): \delta 52.9\left(\mathrm{CO}_{2} \mathrm{CH}_{3}\right), 53.7$ (C-5), 55.2 and 55.4 $\left(\mathrm{OCH}_{3}\right.$ of $2-\mathrm{N}-\mathrm{C}_{6} \mathrm{H}_{4}-\mathrm{OCH}_{3}-p$ and $\mathrm{OCH}_{3}$ of iminyl- $\mathrm{N}-\mathrm{C}_{6} \mathrm{H}_{4}-$ $\mathrm{OCH}_{3}-p$ ), 134.6 (C-6), 135.1 (C-4), 144.0, 121.9, 114.0, 158.5 (C$1^{\prime}$, C-2', C-3', C-4', respectively, iminyl- $\left.\mathrm{N}-\mathrm{C}_{6} \mathrm{H}_{4}-\mathrm{OCH}_{3}-p\right)$, 139.5, 117.3, 114.1, 156.3 (C-1', C-2', C-3', C-4', respectively, 2-N$\mathrm{C}_{6} \mathrm{H}_{4}-\mathrm{OCH}_{3}-p$ ), 128.2, 128.8, 129.2 (remaining aromatics), 158.2 $(-\mathrm{N}=\mathrm{CH}), 169.3(\mathrm{C}=\mathrm{O})$. Anal. Calcd $\mathrm{C}_{32} \mathrm{H}_{28} \mathrm{~N}_{4} \mathrm{O}_{4}$ : C, 72.2; $\mathrm{H}$, 5.2; N, 10.5. Found: 72.3; H, 4.9; N, 10.7 .

5-Methoxycarbonyl-5-( $N$-p-bromophenylformimidoyl)-2-pbromophenyl-4,6-diphenyl-2,5-dihydro-1,2,3-triazine 3c. Compound 3c was isolated as a yellow solid which fluoresced intensely when exposed to UV light (26\%): $\mathrm{mp} 163-164{ }^{\circ} \mathrm{C}$ (from ethanol). ${ }^{1} \mathrm{H}$ NMR (400 MHz CDCl $\left.\mathrm{CD}_{3}\right): \delta 3.5\left(\mathrm{~s}, \mathrm{OCH}_{3}, 3 \mathrm{H}\right), 6.65-6.67$ (d), $7.35-7.37$ (d), (iminyl-N- $\mathrm{C}_{6} \mathrm{H}_{4}-\mathrm{Br}-p, \mathrm{AA}^{\prime} \mathrm{BB}^{\prime} J_{\mathrm{AB}} 8.7 \mathrm{~Hz}$ ), $7.40-$ 7.42 (m, 6H, aromatic), 7.49-7.52 (d), 7.78-7.80 (d), (2-N- $\mathrm{C}_{6} \mathrm{H}_{4}-$ Br-p, $\mathrm{AA}^{\prime} \mathrm{BB}^{\prime} J_{\mathrm{AB}} 9.1 \mathrm{~Hz}$ ), 7.75-7.76 (m, 4H, aromatic), 8.51 (s, $1 \mathrm{H},-\mathrm{N}=\mathrm{CH}) .{ }^{13} \mathrm{C} \mathrm{NMR}\left(\mathrm{CDCl}_{3}\right): \delta 53.4,53.5\left(\mathrm{C}-5\right.$ and $\left.\mathrm{OCH}_{3}\right)$, 134.6, 135.9 (C-6 and C-4), 149.4, 122.1, 129.8, 120.0 (C-1', C-2', C-3', C-4', respectively, iminyl- $\left.\mathrm{N}-\mathrm{C}_{6} \mathrm{H}_{4}-\mathrm{Br}-\mathrm{p}\right)$, 144.2, 117.7, 128.5, 116.5 (C-1', C-2', C-3', C-4', respectively, 2- $\mathrm{N}-\mathrm{C}_{6} \mathrm{H}_{4}-\mathrm{Br}-$ p), 131.8, 132.8 (overlapping aromatics), $161.0(-\mathrm{N}=\mathrm{CH}), 170.0$ $(\mathrm{C}=\mathrm{O})$. Anal. Calcd for $\mathrm{C}_{30} \mathrm{H}_{22} \mathrm{Br}_{2} \mathrm{~N}_{4} \mathrm{O}_{2}$ : C, 57.1; H, 3.4; N, 8.9. Found: C, 57.2; H, 3.6; N, 9.1.

5-Methoxycarbonyl-5-( $N$-p-chlorophenylformimidoyl)-2-pchlorophenyl-4,6-diphenyl-2,5-dihydro-1,2,3-triazine 3d. Compound $3 \mathbf{d}$ was isolated as a yellow solid that fluoresced intensely when exposed to UV light (33\%): $\mathrm{mp} 158-159^{\circ} \mathrm{C}$ (from ethanol). ${ }^{1} \mathrm{H}$ NMR (400 MHz $\mathrm{CDCl}_{3}$ ): $\delta 3.54$ (s, 3H, $\mathrm{OCH}_{3}$ ), 6.70-6.72 (d), 7.19-7.21 (d), (iminyl N- $\mathrm{C}_{6} \mathrm{H}_{4}-\mathrm{Cl}-p$, $\mathrm{AA}^{\prime} \mathrm{BB}^{\prime} J_{\mathrm{AB}} 8.4 \mathrm{~Hz}$ ), $7.35-7.37$ (d), $7.83-7.85$ (d), (2-N- $\mathrm{C}_{6} \mathrm{H}_{4}-\mathrm{Cl}-p, \mathrm{AA}^{\prime} \mathrm{BB}^{\prime} J_{\mathrm{AB}} 9.1$ $\mathrm{Hz}$ ), 7.40-7.42 (m, 6H, aromatic), 7.74-7.75 (m, 4H, aromatic), $8.48(\mathrm{~s}, 1 \mathrm{H},-\mathrm{N}=\mathrm{CH}) ;{ }^{13} \mathrm{C}$ NMR $\left(\mathrm{CDCl}_{3}\right): \delta 53.4$ and $53.5(\mathrm{C}-5$ and $\left.\mathrm{OCH}_{3}\right), 134.6$ (C-6), 135.7 (C-4), 149.3, 121.7, 129.1, 132.1, (C-1', C-2', C-3', C-4', respectively, iminyl- $\left.\mathrm{N}-\mathrm{C}_{6} \mathrm{H}_{4}-\mathrm{Cl}-p\right)$ 143.7, 117.2, 128.9, 128.8 (C-1', C-2', C-3', C-4', respectively, 2-N$\mathrm{C}_{6} \mathrm{H}_{4}-\mathrm{Cl}-p$ ), 129.8, 128.4, 128.5 (remaining aromatics), 160.9 $(-\mathrm{N}=\mathrm{CH}), 170.0(\mathrm{C}=\mathrm{O})$. IR (neat, $\left.\mathrm{cm}^{-1}\right): 1740(\mathrm{C}=\mathrm{O}), 1598(\mathrm{C}=$ N). Anal. Calcd for $\mathrm{C}_{30} \mathrm{H}_{22} \mathrm{Cl}_{2} \mathrm{~N}_{4} \mathrm{O}_{2}$ : C, 66.6; $\mathrm{H}, 4.1 ; \mathrm{N}, 10.3$. Found: C, 66.4; H, 4.1; N, 10.2.

5-Methoxycarbonyl-5-( $N$-p-nitrophenylformimidoyl)-2-p-nitrophenyl-4,6, diphenyl-2,5-dihydro-1,2,3-triazine 3e: Compound 3e was isolated as a yellow solid which fluoresced intensely when exposed to UV light (29\%): mp $213-214{ }^{\circ} \mathrm{C}$ (from ethanol). ${ }^{1} \mathrm{H}$ NMR (400 MHz $\left.\mathrm{CDCl}_{3}\right): \delta 3.58\left(\mathrm{~s}, \mathrm{OCH}_{3}, 3 \mathrm{H}\right), 6.69-6.72$ (d), 8.08-8.10 (d), (iminyl- $\mathrm{N}-\mathrm{C}_{6} \mathrm{H}_{4}-\mathrm{NO}_{2}-p, \mathrm{AA}^{\prime} \mathrm{BB}^{\prime} J_{\mathrm{AB}} 8.7 \mathrm{~Hz}$ ), 7.45-7.46 (m, 6H, aromatic), 7.73-7.75 (m, 4H, aromatic), 7.978.0 (d), 8.27-8.29 (d), (2-N- $\left.\mathrm{C}_{6} \mathrm{H}_{4}-\mathrm{NO}_{2}-p, \mathrm{AA}^{\prime} \mathrm{BB}^{\prime} J_{\mathrm{AB}} 9.6 \mathrm{~Hz}\right)$. $8.71(\mathrm{~s}, 1 \mathrm{H},-\mathrm{N}=\mathrm{CH}) .{ }^{13} \mathrm{C} \mathrm{NMR}\left(\mathrm{CDCl}_{3}\right): \delta 53.9\left(\mathrm{OCH}_{3}\right), 53.1$ (C-5), 134.1 (C-6), 138.2 (C-4), 156.1, 120.5, 128.9, 145.9 (C-1', C-2', C-3', C-4', respectively, iminyl- $\mathrm{N}-\mathrm{C}_{6} \mathrm{H}_{4}-\mathrm{NO}_{2}-p$ ), 149.1, 115.4, 128.5, 143.4 (C-1', C-2', C-3', C-4,' respectively, 2-N$\left.\mathrm{C}_{6} \mathrm{H}_{4}-\mathrm{NO}_{2}-p\right), 118.8,124.9,125.2,130.5$ (remaining aromatics), $163.6(-\mathrm{N}=\mathrm{CH}), 169.4(\mathrm{C}=\mathrm{O})$. Anal. Calcd for $\mathrm{C}_{30} \mathrm{H}_{22} \mathrm{~N}_{6} \mathrm{O}_{6}$ : C, 64.0; H, 3.9; N, 14.9. Found: C, 64.11; H, 3.67; N, 14.74.

6-Methoxycarbonyl-2,3a,4,6a-tetraphenyl-3,3a,4,6a-tetrahydropyrrolo[2,3-d]-[1,2,3]-triazol-2-ium-3-ide 5a. Compound 5a was isolated as a yellow solid (13\%): mp $164-166{ }^{\circ} \mathrm{C}$ (from ethanol). ${ }^{1} \mathrm{H}$ NMR (400 MHz $\left.\mathrm{CDCl}_{3}\right): \delta 3.6$ (s, 3H, $\mathrm{CO}_{2} \mathrm{CH}_{3}$ ), 6.89-7.0 (m, 10H, aromatic), 7.06-7.09 (m, 4H, aromatic), 7.25$7.26\left(\mathrm{~m}, 4 \mathrm{H}\right.$, aromatic), 7.66-7.68 (m, $\left.2 \mathrm{H}, 2-\mathrm{N}-\mathrm{Ph}, \mathrm{H}_{\text {ortho }}\right), 8.40$ (s, $1 \mathrm{H}, 5-\mathrm{CH}) .{ }^{13} \mathrm{C}$ NMR $\left(\mathrm{CDCl}_{3}\right): \delta 51.2\left(\mathrm{OCH}_{3}\right), 92.9$ (C-6a), 105.8 (C-3a), 107.4 (C-6), 135.9 (C-1', 6a-Ph), 137.6 (C-1', 3a$\mathrm{Ph}), 140.6,127.0,123.2,129.1$ (C-1', C-2', C-3', C-4', respectively, 2-N-phenyl ring), 139.5, 118.2, 122.9, 128.5 (C-1', C-2', C-3', C-4', respectively, 4-N-phenyl ring), 132.0, 129.2, 127.7, 127.6, (remaining aromatics), 149.1 (C-5), $165.5(\mathrm{C}=\mathrm{O}) . \mathrm{IR}(\mathrm{NaCl}) v \mathrm{~cm}^{-1}: 1705$ 
$(\mathrm{C}=0)$. Anal. Calcd for $\mathrm{C}_{30} \mathrm{H}_{24} \mathrm{~N}_{4} \mathrm{O}_{2}$ : C, 76.3; H, 5.1; N, 11.9. Found: C, 76.1; H, 4.9; N, 11.6.

6-Methoxycarbonyl-3a,6a-diphenyl-2,4-bis(p-methoxyphenyl)3,3a,4,6a-tetrahydropyrrolo[2,3-d][1,2,3]triazol-2-ium-3-ide 5b. Compound 5b was isolated as a yellow solid (8\%): mp 145-146 ${ }^{\circ} \mathrm{C}$ (from ethanol). ${ }^{1} \mathrm{H}$ NMR (400 $\mathrm{MHz} \mathrm{CDCl}_{3}$ ): $\delta 3.64$ (s, 3H), 3.69 (s, 3H), $\left(2-\mathrm{N}-\mathrm{C}_{6} \mathrm{H}_{4}-\mathrm{OCH}_{3}-p\right.$ and $\left.4-\mathrm{N}-\mathrm{C}_{6} \mathrm{H}_{4}-\mathrm{OCH}_{3}-p\right), 3.89$ (s, $3 \mathrm{H}, \mathrm{CO}_{2} \mathrm{CH}_{3}$ ), 6.70-6.72 (d), 8.37-8.39 (d), (2-N- $\mathrm{C}_{6} \mathrm{H}_{4}-$ $\mathrm{OCH}_{3}-p, \mathrm{AA}^{\prime} \mathrm{BB}^{\prime} J_{\mathrm{AB}} 9.1 \mathrm{~Hz}$ ), 6.90-7.0 (m, 10H, aromatic), 6.987.0 (d), 7.17-7.19 (d), (4-N- $\left.\mathrm{C}_{6} \mathrm{H}_{4}-\mathrm{OCH}_{3}-p, \mathrm{AA}^{\prime} \mathrm{BB}^{\prime} J_{\mathrm{AB}} 9.1 \mathrm{~Hz}\right)$, $8.28(\mathrm{~s}, 1 \mathrm{H}, 5-\mathrm{CH}) .{ }^{13} \mathrm{C} \mathrm{NMR}\left(\mathrm{CDCl}_{3}\right): \delta 51.0\left(\mathrm{CO}_{2} \mathrm{CH}_{3}\right), 55.4$, $55.8\left(2-\mathrm{N}-\mathrm{C}_{6} \mathrm{H}_{4}-\mathrm{OCH}_{3}-p\right.$ and $\left.4-\mathrm{N}-\mathrm{C}_{6} \mathrm{H}_{4}-\mathrm{OCH}_{3}-p\right)$, 92.9 (C-6a), 105.7 (C-3a), 107.4 (C-6), 127.0 (C-1', 6a-Ph), 131.9 (C-1', 3a$\mathrm{Ph}), 137.8,122.9,129.0,162.3$ (C-1', C-2', C-3', C-4', respectively, $\left.2-\mathrm{N}-\mathrm{C}_{6} \mathrm{H}_{4}-\mathrm{OCH}_{3}-p\right), 136.0,123.2,118.2,155.6$ (C-1', C-2', C-3', $\mathrm{C}-4^{\prime}$, respectively, $4-\mathrm{N}-\mathrm{C}_{6} \mathrm{H}_{4}-\mathrm{OCH}_{3}-p$ ), 127.6, 129.2 (remaining aromatics), $149.0(\mathrm{C}-5), 165.5(\mathrm{C}=\mathrm{O})$. Anal. Calcd for $\mathrm{C}_{32} \mathrm{H}_{28} \mathrm{~N}_{4} \mathrm{O}_{4}$ : C, 72.1; H, 5.3; N, 10.5. Found: C, 71.8; H, 5.5; N, 10.7.

6-Methoxycarbonyl-3a,6a-diphenyl-2,4-bis(p-bromophenyl)3,3a,4,6a-tetrahydropyrrolo[2,3-d][1,2,3]triazol-2-ium-3-ide 5c. Compound 5c was isolated as a yellow solid (35\%): mp 169-170 ${ }^{\circ} \mathrm{C}$ (from ethanol). ${ }^{1} \mathrm{H}$ NMR (400 $\left.\mathrm{MHz} \mathrm{CDCl}_{3}\right): \delta 3.6(\mathrm{~s}, 1 \mathrm{H}$, $\mathrm{OCH}_{3}$ ), 6.88-6.96 (m, 10H, aromatic), 7.07-7.09 (d), 7.25-7.27 (d), (4-N- $\left.\mathrm{C}_{6} \mathrm{H}_{4}-\mathrm{Br}-p, \mathrm{AA}^{\prime} \mathrm{BB}^{\prime} J_{\mathrm{AB}} 9.1 \mathrm{~Hz}\right), 7.65-7.67$ (d), 8.308.33 (d), (2-N- $\left.\mathrm{C}_{6} \mathrm{H}_{4}-\mathrm{Br}-p, \mathrm{AA}^{\prime} \mathrm{BB}^{\prime} J_{\mathrm{AB}} 8.7 \mathrm{~Hz}\right), 8.32(\mathrm{~s}, 1 \mathrm{H}$, 5-CH). ${ }^{13} \mathrm{C} \mathrm{NMR}\left(\mathrm{CDCl}_{3}\right): \delta 51.2\left(\mathrm{OCH}_{3}\right), 93.0(\mathrm{C}-6 \mathrm{a}), 105.6(\mathrm{C}-$ 3a), 108.1 (C-6), 135.4 (C-1', 6a-Ph), 137.1 (C-1', 3a-Ph), 139.3, 124.7, 132.3, 126.4 (C-1', C-2', C-3', C-4', respectively, 2-N$\left.\mathrm{C}_{6} \mathrm{H}_{4}-\mathrm{Br}-p\right)$, 138.3, 119.5, 132.2, 115.5 (4-N- $\left.\mathrm{C}_{6} \mathrm{H}_{4}-\mathrm{Br}-p\right)$, 127.9, 127.7, 127.5, 127.2 (remaining aromatics), 148.4, (C-5), 165.2 (C= O). Anal. Calcd for $\mathrm{C}_{30} \mathrm{H}_{22} \mathrm{Br}_{2} \mathrm{~N}_{4} \mathrm{O}_{2}$ : C, 57.2; H, 3.5; N, 8.9. Found: C, 57.3; H, 3.4; N, 8.5.

6-Methoxycarbonyl-3a,6a-diphenyl-2,4-bis(p-chlorophenyl)3,3a,4,6a-tetrahydropyrrolo[2,3-d][1,2,3]triazo-2-ium-3-ide 5d. Compound 5d was isolated as a yellow solid (25\%): mp 163$164{ }^{\circ} \mathrm{C}$ (from ethanol). ${ }^{1} \mathrm{H}$ NMR (400 $\left.\mathrm{MHz} \mathrm{CDCl}_{3}\right): \delta 3.66(\mathrm{t}$, $3 \mathrm{H}, \mathrm{CO}_{2} \mathrm{CH}_{2} \mathrm{CH}_{3}$ ), 6.92-6.94 (m, 10H, aromatic), 7.13-7.16 (m, $4 \mathrm{H}$, aromatic), $7.50-7.52$ (d), $8.38-8.41$ (d), (2-N- $\mathrm{C}_{6} \mathrm{H}_{4}-\mathrm{Cl}-\mathrm{p}$, $\left.\mathrm{AA}^{\prime} \mathrm{BB}^{\prime} J_{\mathrm{AB}} 9 \mathrm{~Hz}\right), 8.34$ (s, $\left.1 \mathrm{H}, 5-\mathrm{CH}\right) .{ }^{13} \mathrm{C}$ NMR $\left(\mathrm{CDCl}_{3}\right): \delta 51.2$ $\left(\mathrm{OCH}_{3}\right)$, 93.0 (C-6a), 105.7 (C-3a), 107.9 (C-6), 135.3 (C-1', 6a$\mathrm{Ph})$, 137.1 (C-1', 3a-Ph), 138.8, 124.5, 127.7, 137.8 (C-1', C-2', C-3', C-4', respectively, 2-N- $\left.\mathrm{C}_{6} \mathrm{H}_{4}-\mathrm{Cl}-p\right)$, 138.2, 119.2, 127.8, 127.2 (C-1', C-2', C-3', C-4', respectively, 4- $\left.\mathrm{N}-\mathrm{C}_{6} \mathrm{H}_{4}-\mathrm{Cl}-p\right)$, 128.0, 129.2, 127.5, 127.6 (overlapping aromatics), 148.5 (C-5), 165.2 (C= O). Anal. Calcd for $\mathrm{C}_{30} \mathrm{H}_{22} \mathrm{Cl}_{2} \mathrm{~N}_{4} \mathrm{O}_{2}$ : C, 66.5; H, 4.0; N, 10.3 . Found: C, 66.8; H, 3.80, N, 10.0.

6-Methoxycarbonyl-3a,6a-diphenyl-2,4-bis(p-nitrophenyl)3,3a,4,6a-tetrahydropyrrolo[2,3-d][1,2,3]triazo-2-ium-3-ide 5e. Compound 5e was isolated as a yellow solid (25\%): mp 143-144 ${ }^{\circ} \mathrm{C}$ (from ethanol). ${ }^{1} \mathrm{H}$ NMR (400 MHz CDCl $): \delta 3.69(\mathrm{~s}, 3 \mathrm{H}$, $\mathrm{OCH}_{3}$ ), 6.92-7.01 (m, 10H, aromatic), 7.23-7.25 (d), 8.04-8.05 (d), (4-N-C $\left.\mathrm{C}_{6} \mathrm{H}_{4}-\mathrm{NO}_{2}-p, \mathrm{AA}^{\prime} \mathrm{BB}^{\prime} J_{\mathrm{AB}} 7.7 \mathrm{~Hz}\right), 8.40-8.42$ (d), 8.65-8.67 (d), (2-N- $\left.\mathrm{C}_{6} \mathrm{H}_{4}-\mathrm{NO}_{2}-p, \mathrm{AA}^{\prime} \mathrm{BB}^{\prime} J_{\mathrm{AB}} 8.3 \mathrm{~Hz}\right), 8.46$ (s, $1 \mathrm{H}, 5-\mathrm{CH}) .{ }^{13} \mathrm{C} \mathrm{NMR}\left(\mathrm{CDCl}_{3}\right): \delta 51.6\left(\mathrm{OCH}_{3}\right), 93.2(\mathrm{C}-6 \mathrm{a}), 105.6$ (C-3a), 134.5 (C-1', 6a-Ph), 136.1 (C-1', 3a-Ph), 111.5 (C-6), 144.0, 124.4, 125.4, 146.5 (C-1', C-2', C-3', C-4', respectively, 2-N$\left.\mathrm{C}_{6} \mathrm{H}_{4}-\mathrm{NO}_{2}-p\right)$, 144.4, 117.0, 124.6, 142.0 (C-1', C-2', C-3', C-4', respectively, 4- $\mathrm{N}-\mathrm{C}_{6} \mathrm{H}_{4}-\mathrm{NO}_{2}-p$ ), 127.9, 124.5 (remaining overlapping aromatic signals), $149.8(\mathrm{C}-5), 164.5(\mathrm{C}=\mathrm{O})$. Anal. Calcd for $\mathrm{C}_{30} \mathrm{H}_{22} \mathrm{~N}_{6} \mathrm{O}_{6}$ : C, 64.0; $\mathrm{H}, 3.9 ; \mathrm{N}, 14.9$. Found: C, 64.1; H, 4.0; N, 15.1.

Hydrolytic Degradation of 2 and 3 to 6 and 7. Synthesis of 5-Ethoxycarbonyl-5- $\mathrm{H}$-2,4,6-triphenyl-2,5-dihydro-1,2,3-triazine 6. A solution of $2 \mathrm{a}(0.15 \mathrm{~g}, 0.30 \mathrm{mmol})$ in a $(1: 1 \mathrm{v} / \mathrm{v})$ mixture of aqueous ethanol $\left(40 \mathrm{~cm}^{3}\right)$ was stirred under reflux for 7 days, cooled, extracted with methylene chloride $\left(4 \times 10 \mathrm{~cm}^{3}\right)$, and the combined extract was dried over $\mathrm{MgSO}_{4}$ and evaporated under reduced pressure. The residue (A) in $\mathrm{CH}_{2} \mathrm{Cl}_{2}\left(2.0 \mathrm{~cm}^{3}\right)$ was placed on a silica gel column (230-400 mesh ASTM), and the column was eluted with a gradient mixture (1:0 to $1: 1)(\mathrm{v} / \mathrm{v})$ of petroleum spirit (bp $40-60{ }^{\circ} \mathrm{C}$ )/ethyl acetate using a $2.5 \%$ (v/v) changing gradient to give the product $6(0.08 \mathrm{~g}, 72 \%)$ : $\mathrm{mp} 142-143{ }^{\circ} \mathrm{C}$ (from $\mathrm{CH}_{2} \mathrm{Cl}_{2}$ : hexane). ${ }^{1} \mathrm{H}$ NMR $\left(400 \mathrm{MHz} \mathrm{CDCl}_{3}\right): \delta 0.86$ (t, $3 \mathrm{H}, \mathrm{CO}_{2} \mathrm{CH}_{2} \mathrm{CH}_{3}$ ), 4.1 (q, 2H, $\mathrm{CO}_{2} \mathrm{CH}_{2} \mathrm{CH}_{3}$ ), 5.28 (s, $1 \mathrm{H}, 5-\mathrm{CH}$ ), 7.38-7.48 (m, 9H, aromatic), $7.88-8.04$ (m, $6 \mathrm{H}$, aromatic). ${ }^{13} \mathrm{C}$ NMR $\left(\mathrm{CDCl}_{3}\right): \delta 14.0\left(\mathrm{OCH}_{3}\right), 38.8(\mathrm{C}-5) 62.3\left(\mathrm{CO}_{2} \mathrm{CH}_{2} \mathrm{CH}_{3}\right)$, 134.1, 134.6 (C-4, C-6), 144.3, 117.3, 128.8, 126.8 (C-1', C-2', C-3', C-4', respectively, 2-N-Ph), 126.8, 128.8, 130.0 (remaining aromatics). IR ( $\mathrm{NaCl}) v \mathrm{~cm}^{-1}, 1742(\mathrm{C}=\mathrm{O})$. Anal. Calcd for $\mathrm{C}_{24} \mathrm{H}_{21} \mathrm{~N}_{3} \mathrm{O}_{2}$ : C, 75.1; H, 5.5; N, 10.9. Found: C, 74.9; H, 5.3; N, 11.1. Formanilide (ca. 60\%) and aniline were detected by TLC and estimated by ${ }^{1} \mathrm{H}$ NMR in residue (A) prior to column chromatography. These products were also isolated from the column but in lesser quantities than in residue (A) because of losses on the column. Similar results were obtained for a reaction under nitrogen atmosphere. Compound 7 was obtained in a similar fashion.

5-Methoxycarbonyl-5-H-2,4,6-triphenyl-2,5-dihydro-1,2,3-triazine 7. Compound 7 was isolated as a yellow fluorescent solid (92\%): mp 193-196 ${ }^{\circ} \mathrm{C}\left(\mathrm{CH}_{2} \mathrm{Cl}_{2}\right.$ : hexane). ${ }^{1} \mathrm{H}$ NMR $(400 \mathrm{MHz}$ $\left.\mathrm{CDCl}_{3}\right): \delta 3.65\left(\mathrm{~s}, 3 \mathrm{H}, \mathrm{OCH}_{3}\right), 5.32(\mathrm{~s}, 1 \mathrm{H}, 5-\mathrm{CH}), 7.43-7.48$ (m, 9H, aromatic), 7.96-8.04 (m, 6H, aromatic). ${ }^{13} \mathrm{C}$ NMR $\left(\mathrm{CDCl}_{3}\right): \delta 38.4(\mathrm{C}-5), 53.2\left(-\mathrm{OCH}_{3}\right), 134.7,134.8$ (C-6 and C-4), 145.7, 116.2, 128.9, 123.5 (C-1', C-2', C-3', C-4', respectively, 2-Nphenylring), 126.6, 128.7, 129.8, 133.3 (remaining aromatics), 167.8 $(\mathrm{C}=\mathrm{O})$. IR $(\mathrm{NaCl}) v \mathrm{~cm}^{-1}$ : $1742(\mathrm{C}=\mathrm{O})$. Anal. Calcd for $\mathrm{C}_{23} \mathrm{H}_{19} \mathrm{~N}_{3} \mathrm{O}_{2}$ : C, 74.8; H, 5.2; N, 11.4. Found: C, 74.3; H, 5.1; N, 11.2.

Reactions in Water and under Solvent Free Conditions. (i) A suspension of 2,4,5-triphenyl-1,2,3-triazolium-1-phenylaminide 1a $(0.3 \mathrm{~g}, 0.77 \mathrm{mmol})$ in water $\left(7 \mathrm{~cm}^{3}\right)$ was treated with an excess of methyl propiolate $\left(0.14 \mathrm{~cm}^{3}, 1.57 \mathrm{mmol}\right)$, stirred at $90{ }^{\circ} \mathrm{C}$ for $24 \mathrm{~h}$, and extracted into methylene chloride $\left(4 \times 10 \mathrm{~cm}^{3}\right)$. The combined extracts were dried over $\mathrm{MgSO}_{4}$ and evaporated under reduced pressure, and the residue, in methylene chloride $\left(2 \mathrm{~cm}^{3}\right)$, was placed on a silica gel column (230-400 mesh ASTM). The column was eluted with a gradient mixture (1:0 to 2:1 v/v) of petroleum spirit (bp $40-60{ }^{\circ} \mathrm{C}$ )/methylene chloride using a $2.5 \%$ (v/v) changing gradient. The first eluant was 7 (7\%). The major product 3a was subsequently obtained in a high yield of $81 \%$.

(ii) 2,4,5-triphenyl-1,2,3-triazolium-1-phenylaminide $\mathbf{1 a}(0.1 \mathrm{~g}$, $0.26 \mathrm{mmol}$ ) in a test tube was treated dropwise with methyl propiolate $\left(0.023 \mathrm{~cm}^{3}, 0.26 \mathrm{mmol}\right)$, and the stoppered test tube was heated at $60^{\circ} \mathrm{C}$ for $1 \mathrm{~h}$. The residue in methylene chloride $\left(2 \mathrm{~cm}^{3}\right)$ was placed on a silica gel column (230-400 mesh ASTM). Elution with a gradient mixture $(1: 0$ to $1: 1 \mathrm{v} / \mathrm{v})$ of petroleum spirit (bp 40-60 ${ }^{\circ} \mathrm{C}$ )/methylene chloride gave 3a (73\%).

Cyclooctano-1,2,3-triazolium-1-p-nitrophenylaminide-1,3dipole 8. A solution of d,L-trans-1,2-cyclooctanediol (12.5 g, 86.8 mmol) and dibutyl tin oxide (21.6 g, $86.8 \mathrm{mmol})$ in $250 \mathrm{~cm}^{3}$ of toluene was heated under reflux until $2 \mathrm{~cm}^{3}$ of water had been collected in the Dean Stark trap (ca. 4 h). Evaporation of the solvent under reduced pressure gave a syrup which was crystallized from petroleum spirit (bp $90-100{ }^{\circ} \mathrm{C}$ ) to give a white crystalline solid cyclooctane-1,2-di-((n-butyl)tin (1V) ether (15 g, 71\%): mp 160$162{ }^{\circ} \mathrm{C}$ (from petroleum spirit (bp $90-100{ }^{\circ} \mathrm{C}$ ). Anal. Calcd $\mathrm{C}_{16} \mathrm{H}_{32} \mathrm{O}_{2} \mathrm{Sn}$ : C, 51.3; H, 8.5. Found: C, 51.0; H, 8.4.

A solution of the crude white solid (15 g, $0.04 \mathrm{~mol})$ in dichloromethane $\left(50 \mathrm{~cm}^{3}\right)$ was treated dropwise with bromine $(2.06$ $\mathrm{g}, 0.04 \mathrm{~mol})$ in dichloromethane $\left(16 \mathrm{~cm}^{3}\right)$ while stirring over a 30 min period, after which the solvent was allowed to evaporate to the open air in a fumehood. The crude 2-hydroxy cyclooctanone oily product $(5.7 \mathrm{~g}, 0.04 \mathrm{~mol})$ was immediately treated with p-nitrophenylhydrazine $(12.2 \mathrm{~g}, 0.08 \mathrm{~mol})$ in acetic acid $\left(200 \mathrm{~cm}^{3}\right)$, and the mixture was heated under reflux for 40 min during which time 1,2-bis( $p$-nitrophenyl)hydrazone of cyclooctan-1,2-dione precipitated (8.70 g, 53\%): mp 240-242 ${ }^{\circ} \mathrm{C}$ (from 1,4-dioxane). ${ }^{1} \mathrm{H}$ NMR (250 MHz DMSO-d $\left.d_{6}\right)$ 1.47-1.90 (m, 8H, cyclooctyl), 2.67- 
2.78 (m, 4H, cyclooctyl), 7.21-7.23 (d), ( $\mathrm{H}_{\text {ortho }}$ of $\mathrm{AA}^{\prime} \mathrm{BB}^{\prime}$ of $\mathrm{NH}-$ $\mathrm{C}_{6} \mathrm{H}_{4}-\mathrm{NO}_{2}-p, J_{\mathrm{AB}} 8.8 \mathrm{~Hz}$,), 7.3-7.32 (d), ( $\mathrm{H}_{\text {ortho }}$ of $\mathrm{AA}^{\prime} \mathrm{BB}^{\prime}$ of $\left.\mathrm{NH}-\mathrm{C}_{6} \mathrm{H}_{4}-\mathrm{NO}_{2}-p, J_{\mathrm{AB}} 9.3 \mathrm{~Hz}\right), 8.14-8.16(\mathrm{~d}),\left(\mathrm{H}_{\text {meta }}\right.$ of $\mathrm{AA}^{\prime} \mathrm{BB}^{\prime}$ of $\left.\mathrm{NH}-\mathrm{C}_{6} \mathrm{H}_{4}-\mathrm{NO}_{2}-p\right), 8.23-8.26$ (d), $\left(\mathrm{H}_{\text {meta }}\right.$ of $\mathrm{AA}^{\prime} \mathrm{BB}^{\prime}$ of $\mathrm{NH}-$ $\mathrm{C}_{6} \mathrm{H}_{4}-\mathrm{NO}_{2}-p$ ), 10.5 (bs, $1 \mathrm{H}, \mathrm{NH}$ ), 12.42 (bs, $1 \mathrm{H}, \mathrm{NH}$, intramolecular H-bonded of ZE form). ${ }^{13} \mathrm{C}$ NMR (DMSO- $d_{6}$ ) 25.0, 25.5, 25.4, 26.8, 29.4, 35.3 (methylene chain), 150.2, 112.2, 126.1, 139.1 $\left(\mathrm{C}-1^{\prime}, \mathrm{C}-2^{\prime}, \mathrm{C}-3^{\prime}, \mathrm{C}-4^{\prime}\right.$ of $\left.\mathrm{NH}-\mathrm{C}_{6} \mathrm{H}_{4}-\mathrm{NO}_{2}-p\right), 145.2(>\mathrm{C}=\mathrm{N}-)$, $149.2(>\mathrm{C}=\mathrm{N}-), 151.4,112.4,139.5\left(\mathrm{C}-1^{\prime}, \mathrm{C}-2^{\prime}, \mathrm{C}-3^{\prime}, \mathrm{C}-4^{\prime}\right.$ of $\mathrm{NH}-\mathrm{C}_{6} \mathrm{H}_{4}-\mathrm{NO}_{2}-p$, one overlapping signal). Anal. Calcd for $\mathrm{C}_{20} \mathrm{H}_{22} \mathrm{~N}_{6} \mathrm{O}_{4}$ : C, 58.5; H, 5.4; N, 20.5. Found: C, 58.4; H, 5.3; N, 20.6 .

A suspension of 1,2-bis( $p$-nitrophenyl)hydrazone of cyclooctanone-1,2-dione (2 g, $4.88 \mathrm{mmol}$ ) in dry methylene chloride (60 $\mathrm{cm}^{3}$ ) was treated with lead dioxide (5 g, $\left.20.9 \mathrm{mmol}\right)$ and stirred at ambient temperature for $48 \mathrm{~h}$. The lead salts were removed by filtration through Celite after which the filtrate was evaporated under reduced pressure to give 8 , a red crystalline solid (0.92 g, 46\%); mp $173-174{ }^{\circ} \mathrm{C}$ (from acetone). ${ }^{1} \mathrm{H}$ NMR (400 $\left.\mathrm{MHz} \mathrm{CDCl}_{3}\right): \delta$ 1.65 (m, 4H, cyclooctyl $\left.\mathrm{CH}_{2}\right), 1.93\left(\mathrm{~m}, 4 \mathrm{H}\right.$, cyclooctyl $\left.\mathrm{CH}_{2}\right), 2.94$ (m, $4 \mathrm{H}$, cyclooctyl $\left.\mathrm{CH}_{2}\right), 6.13\left(2 \mathrm{H}, \mathrm{H}_{\text {ortho }}\right.$ of 1-aminide- $p-\mathrm{NO}_{2}-$ $\mathrm{C}_{6} \mathrm{H}_{4}$, broad collapsed doublet due to an aryl ring exchange ${ }^{21}$ in the 1,2-bisazo form), $8.01\left(6 \mathrm{H}, \mathrm{H}_{\text {ortho }}\right.$ of $2-p-\mathrm{NO}_{2}-\mathrm{C}_{6} \mathrm{H}_{4}$ and $\mathrm{H}_{\text {meta }}$ of -aminide- $p-\mathrm{NO}_{2}-\mathrm{C}_{6} \mathrm{H}_{4}$, broad collapsed multiplet due to aryl ring exchange $\left.{ }^{21}\right) .{ }^{13} \mathrm{C}$ NMR $\left(\mathrm{CDCl}_{3}\right)$ : 26.3 (broad), 30.4, 112.1 (broad), 126.1 (exchange ${ }^{21}$ broadened), $142.8(\mathrm{C}=\mathrm{N})$. Anal. Calcd for $\mathrm{C}_{20} \mathrm{H}_{20} \mathrm{~N}_{6} \mathrm{O}_{4}$ : C, 58.8; H, 4.9; N, 20.4. Found: C, 58.6; H, 5.1; N, 20.4 .

2,4-bis-p-Nitrophenyl-6-methoxycarbonyl-3a,6a-hexamethylene-3,3a,4,6a-tetrahydropyrrolo-[2,3-d]-1,2,3-triazol-2-ium-3ide 9. A solution of $8(0.5 \mathrm{~g}, 1.22 \mathrm{mmol})$ in dry acetone $\left(6 \mathrm{~cm}^{3}\right)$ was treated with methyl propiolate $\left(0.19 \mathrm{~cm}^{3}, 2.14 \mathrm{mmol}\right)$, stirred under reflux for $3 \mathrm{~h}$ during which time the product 9 precipitated as a yellow powder $(0.51 \mathrm{~g}, 85 \%)$ : $\mathrm{mp} 159-161{ }^{\circ} \mathrm{C}$ (from EtOH). ${ }^{1} \mathrm{H}$ NMR (250 MHz CDCl $)$ : $1.11-1.78$ (m, 8H, cyclooctyl), 2.022.04 (m, 1H, cyclooctyl), 2.18-2.24 (m, 1H, cyclooctyl), 2.692.73 (m, 1H, cyclooctyl), 2.92-2.94 (m, $1 \mathrm{H}$, cyclooctyl), 3.81 (s, $\left.3 \mathrm{H}, \mathrm{OCH}_{3}\right), 7.53-7.55(\mathrm{~d}), 8.24-8.27$ (d), $\left(4-\mathrm{N}-\mathrm{C}_{6} \mathrm{H}_{4}-\mathrm{NO}_{2}-p\right.$, $\mathrm{AA}^{\prime} \mathrm{BB}^{\prime} J_{\mathrm{AB}} 9.3 \mathrm{~Hz}$ ), 7.90 (s, 1H, 5-CH), 8.31-8.32 (d), 8.378.40 (d), $\left(2-\mathrm{N}-\mathrm{C}_{6} \mathrm{H}_{4}-\mathrm{NO}_{2}-p, \mathrm{AA}^{\prime} \mathrm{BB}^{\prime} J_{\mathrm{AB}} 9.3 \mathrm{~Hz}\right) .{ }^{13} \mathrm{C}$ NMR $\left(\mathrm{CDCl}_{3}\right): \quad \delta$ 24.2, 25.1, 25.8, 28.9, 30.0 (methylene chain, one overlapping signal), $51.2\left(\mathrm{OCH}_{3}\right), 88.6$ (C-6a), 101.6 (C-3a), 110.5 (C-6), 144.1, 124.1, 125.6, 149.3 (C-1', C-2', C-3', C-4', respectively, 2-N- $\left.\mathrm{C}_{6} \mathrm{H}_{4}-\mathrm{NO}_{2}-p\right), 145.4,116.9,114.0,142.6\left(\mathrm{C}-1^{\prime}, \mathrm{C}-2^{\prime}\right.$, C-3', C-4', respectively, 4-N- $\mathrm{C}_{6} \mathrm{H}_{4}-\mathrm{NO}_{2}-p$ ), 146.6 (C-5), 164.8 $(\mathrm{C}=\mathrm{O})$. IR $(\mathrm{NaCl}) v \mathrm{~cm}^{-1}: 1705(\mathrm{C}=\mathrm{O})$. Anal. Calcd for $\mathrm{C}_{24} \mathrm{H}_{24} \mathrm{~N}_{6} \mathrm{O}_{6}$ : C, 58.5; H, 4.9; N, 17.1. Found: C, 58.5; H, 4.6; N, 17.1.

(21) Butler, R. N.; Cunningham, M. G. J. Chem. Soc., Perkin Trans. 1 1980, 744-749. Butler, R. N.; Evans, A. M.; Gillan, A. M.; James, J. P.; McNeela, E. M.; Cunningham, D.; McArdle, P. J. Chem. Soc., Perkin Trans. 1 1990, 2537-2544.
X-ray Structure Determinations. X-ray quality single crystals of 3a (CCDC 286736), 7 (CCDC 286737), and 9 (CCDC 601382) were obtained by recrystallization from hexane. Intensity data were

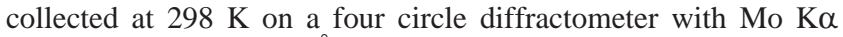
radiation $(\lambda=0.71069 \AA)$ and a graphite monochromator. The structures were solved by direct methods, SHELXS-97,22 and refined by full matrix least squares using SHELXL-97.23 SHELX operations were automated using ORTEX which was also used to obtain the drawings. ${ }^{24}$ All non-hydrogen atoms were refined anisotropically.

X-ray Crystal Data for Compound 3a. $\mathrm{C}_{30} \mathrm{H}_{24} \mathrm{~N}_{4} \mathrm{O}_{2}, M_{\mathrm{r}}=$ $472.53 \mathrm{amu}$; monocyclic, space group $P 21 / n$ with unit cell $a=$ 10.2928(19) $\AA, b=16.430$ (4) $\AA, c=14.593(3) \AA$, and $V=2466.9$ (8) $\AA^{3}$. $D_{\text {calcd }}=1.272 \mathrm{Mg} / \mathrm{m}^{3}, Z=4, T=298(2) \mathrm{K}$, and $\mu$ (Mo $\mathrm{K} \alpha)=0.082 \mathrm{~mm}^{-1}$. The refinement converged to $\mathrm{R} 1=0.0475$, $\mathrm{wR} 2=0.1133(I>2 \sigma(I))$.

X-ray Crystal Data for Compound 7. $\mathrm{C}_{23} \mathrm{H}_{19} \mathrm{~N}_{3} \mathrm{O}_{2}, M_{\mathrm{r}}=$ 369.41 amu; orthorhombic, space group $P 212121$ with unit cell $a$ $=9.9253(13), b=10.973(7), c=17.458(4) \AA$, and $V=1901.4-$ (14) $\AA^{3}$. $D_{\text {calcd }}=1.290 \mathrm{Mg} / \mathrm{m}^{3}, Z=4, T=292(2) \mathrm{K}$, and $\mu$ (Mo $\mathrm{K} \alpha)=0.084 \mathrm{~mm}^{-1}$. The refinement converged to $\mathrm{R} 1=0.0535$, $\mathrm{wR} 2=0.1362(I>2 \sigma(I))$.

X-ray Crystal Data for Compound 9. $\mathrm{C}_{24} \mathrm{H}_{24} \mathrm{~N}_{6} \mathrm{O}_{6}, M_{\mathrm{r}}=492.49$ amu; triclinic, space group $\bar{P} 1$ with unit cell $a=11.2071(14) \AA, b$ $=14.295(2) \AA, c=15.583$ (2) $\AA, \alpha=76.913(12)^{\circ}, \beta=88.719-$ $(10)^{\circ}, \gamma=68.613(12)^{\circ}$, and $V=2259.3$ (5) $\AA^{3}$. $D_{\text {calcd }}=1.448$ $\mathrm{Mg} / \mathrm{m}^{3}, Z=4, T=298(2) \mathrm{K}$, and $\mu(\mathrm{Mo} \mathrm{K} \alpha)=0.107 \mathrm{~mm}^{-1}$. The refinement converged to R1 $=0.0485$, wR2 $=0.1307(I>2 \sigma(I))$. Further information on the structure determinations (excluding structure factors) has been deposited with the Cambridge Crystallographic Data Centre as supplementary publication numbers. Copies of the data can be obtained, free of charge, on application to CCDC, 12 Union Road, Cambridge CB2 1EZ, U.K. [fax: +44(0)-1223-336033 or e-mail: deposit@ccdc.cam.ac.uk].

Acknowledgment. Aoife M. Fahy acknowledges the financial support of the Irish Research Council for Science Engineering and Technology (IRCSET). Alan G. Ryder acknowledges the support of Science Foundation Ireland (Grant No. 02/IN.1/ M231).

Supporting Information Available: Cystallographic information files for compounds $\mathbf{3 a}, \mathbf{7}$, and $\mathbf{9}$ are available in pdf format. This material is available free of charge via the Internet at http://pubs.acs.org.

\section{JO060752X}

(22) Sheldrick, G. M. Acta Crystallogr., Sect. A: Found. Crystallogr. 1990, 46, 467-473.

(23) Sheldrick, G. M. SHELXL-97, Program for Solution of Crystal Structures; University of Göttingen: Göttingen, Germany, 1997.

(24) McArdle, P.; Daly, P.; Cunningham, D. J. Appl. Crystallogr. 2002, 35,378 . 